\title{
Implementasi Metode TwoStep Clustering untuk Klasterisasi Karakteristik Akademik Mahasiswa
}

\author{
Raden Gunawan Santosa ${ }^{\# 1}$, Yuan Lukito ${ }^{\# 2}$, Antonius Rachmat Chrismanto ${ }^{\# 3}$

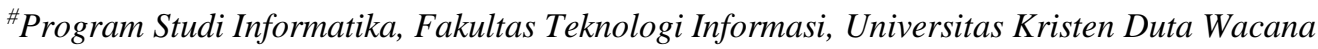 \\ Jl. Dr. Wahidin Sudiro Husodo 5-25, Yogyakarta, Indonesia \\ ${ }^{1}$ gunawanestaff.ukdw.ac.id \\ ${ }^{2}$ yuanlukitoeti.ukdw.ac.id \\ 3antoneti.ukdw.ac.id
}

\begin{abstract}
Abstrak - Salah satu algoritma clustering yang paling banyak dipakai adalah K-Means dimana algoritma ini membutuhkan masukan jumlah klaster yang ingin dibentuk. Pada kenyataannya jumlah klaster yang tepat tidak bisa diketahui sehingga pemilihan nilai $k$ bergantung pada subyektifitas peneliti. Kemudian algoritma K-Means hanya bisa menangani atribut dalam bentuk numerik kontinyu padahal ada atribut dalam bentuk kategorikal atau campuran keduanya. Pada penelitian ini dilakukan pengelompokkan data akademik mahasiswa dengan menggunakan algoritma twostep clustering yang dapat menentukan jumlah klaster secara otomatis dan dapat menangani atribut dalam bentuk kategorikal, numerik kontinyu atau campuran keduanya. Metode twostep clustering diterapkan pada data mahasiswa angkatan 2008-2019 dengan analisis diterapkan pada setiap angkatannya. Penelitian ini menghasilkan klaster-klaster yang mencerminkan tingkat heterogenitas setiap angkatan mahasiswa. Klaster-klaster yang didapat merupakan klaster yang optimal setelah diukur menggunakan Bayesian Information Criterion dan Ratio Distance Measure.
\end{abstract}

Kata kunci - Data Akademik, TwoStep, K-Means, Klasterisasi, Bayesian Information Criterion, Ratio Distance Measure

\section{Pendahuluan}

Dalam dunia yang modern ini dimana informasi memegang peran yang penting, banyak data yang melimpah di sekitar kita. Data-data tersebut akan tidak ada manfaatnya apabila hanya sebagai data mentah yang ada dimedia penyimpanan. Data akan berubah menjadi suatu yang berguna apabila diekstrak menjadi informasi yang mendukung suatu tujuan.

Demikian pula Universitas Kristen Duta Wacana (UKDW) sebagai institusi pendidikan juga mempunyai data yang tersimpan. Oleh karena itu UKDW akan menggunakan data yang ada untuk diproses menjadi Educational Data Mining (EDM).

Ada dua definisi sudut pandang definisi EDM yang meskupun berbeda tapi pada dasarnya mereka sama, yaitu menurut Campbell dan Baker. Penelitian [1] mendefinisikan analisis akademis sebagai penggunaan teknik statistik dan data mining yang akan membantu fakultas dan penasehat akademik menjadi lebih proaktif dalam mengidentifikasi siswa yang beresiko menadapat nilai buruk dan menanggapi sesuai keadaannya. Dengan cara ini, maka hasil data mining dapat digunakan untuk meningkatkan retensi siswa. Analisis akademik berfokus pada proses yang terjadi di departemen, unit, atau perguruan tinggi dan tingkat universitas. Jenis analisis ini tidak berfokus pada detail tetapi analisis akademik memiliki perspektif makro [1].

Penelitian [2] mendefinisikan EDM sebagai "disiplin ilmu yang sedang berkembang, berkaitan dengan mengembangkan metode untuk mengeksplorasi jenis data unik yang berasal dari pengaturan pendidikan, dan menggunakan metode tersebut untuk lebih memahami siswa, dan pengaturan tempat mereka belajar" [2].

Sebagai suatu institusi pendidikan, maka Universitas Kristen Duta Wacana (UKDW) juga ingin melakukan Educational Data Mining (EDM), sehingga data yang ada akan bermanfaat bagi institusi apabila data tersebut bisa menjadi informasi. Informasi tersebut yang pada akhirnya akan menjadi faktor yang akan dipertimbangkan untuk pengambilan keputusan. Sebagai universitas maka diharapkan akan menghasilkan lususan yang berkualitas.

Lulusan adalah sebagai hasil proses pembelajaran di perguruan tinggi itu ternyata juga dipengaruhi dari inputnya. Input disini adalah calon mahasiswa yang berasal dari sekolah menengah atas yang kondisi dan situasinya berbeda-beda. Untuk menghasilkan lulusan yang berkualitas banyak kendala yang dihadapi, misalnya pada input. Hal yang paling penting adalah proses belajar pada awal masuk perguruan tinggi, karena pada masa tersebut merupakan masa peralihan. Perguruan tinggi perlu melakukan identifikasi mahasiswa-mahasiswa baru yang kemungkinan akan mengalami kesulitan pada bidang akademik sehingga bisa memberikan bantuan dan dukungan lebih awal.

Penelitian ini mengimplementasikan algoritma clustering pada data kuliah di Fakultas Teknologi Informasi UKDW untuk dua belas tahun akademik dimulai dari tahun 
2008 sd 2019. Dengan diketahui karakteristik cluster mahasiswa baru yang mendaftar di UKDW maka akan diperoleh mahasiswa yang diharapkan setelah kuliah di UKDW akan mempunyai kategori Indeks Prestasi Semester 1 (IPS1) yang tinggi. Dengan diketahuinya karakteristik IPS 1 yang tinggi, maka akan mengurangi mahasiswa yang drop out atau yang mengundurkan diri. Penelitian ini merupakan kelanjutan dari penelitian sebelumnya tentang prediksi kategori IPK [3] dan analisis cluster terhadap data yang sama [4].

Pada penelitian [4] telah digunakan metode K-Means Clustering dengan $\mathrm{K}=2$ dan $\mathrm{K}=3$, namun hasilnya tidak memuaskan karena pada saat pengelompokan, terdapat klaster yang di dalamnya memuat outlier baik mild outlier ataupun ekstrim outlier. Pada penelitian tersebut juga analisis klaster hanya dilakukan pada mahasiswa Jalur Prestasi. Pada penelitian ini yang dilakukan adalah menggunakan Metode TwoStep Clustering.

Metode ini memiliki keunggulan daripada metode $\mathrm{K}$ Means Clustering [6], [13], [14], yaitu dapat secara dinamis menentukan $\mathrm{K}$ yang cocok pada sekumpulan data berdasarkan nilai BIC atau AIC, sedangkan K-means Clustering menggunakan $\mathrm{K}$ yang tertentu dan tetap bergantung pada asumsi peneliti. Metode TwoStep clustering dapat menangani outlier sedangkan metode $\mathrm{K}$ Means tidak dapat menangani jika dalam sekumpulan data ada kasus outlier. Metode TwoStep clustering dapat diterapkan untuk tipe data kontinu dan kategorik, sedangkan metode K-Means Clustering lebih tepat untuk data yang bertipe numerik kontinu

Tulisan ini disusun dengan sistematika sebagai berikut: bagian pertama Pendahuluan berisi latar belakang dan pengantar tentang pentingnya penelitian, apa yang akan dikerjakan, dan hasil yang diharapkan. Bagian kedua adalah Tinjauan Pustaka dan Landasan Teori berisi referensi-referensi pendukung yang relevan baik berupa artikel primer dan sekunder mengenai metode yang digunakan. Bagian ketiga adalah Metodologi yang menceritakan tentang langkah dan tahapan penelitian yang dilakukan oleh penulis secara valid. Bagian keempat adalah Hasil dan Pembahasan berisi tentang hasil penelitian dan analisis yang dapat disampaikan perihal penelitian yang dilakukan. Bagian akhir ditutup dengan Kesimpulan dan saran untuk pengembangan penelitian lebih lanjut di masa yang akan datang.

\section{TINJAUAN PUSTAKA DAN LANDASAN TEORI}

\section{A. Tinjauan Pustaka}

Metode clustering yang akan diterapkan adalah metode TwoStep Clustering. Beberapa penelitian yang telah dilakukan dengan menggunakan TwoStep Clustering seperti pada penelitian Schiopu mengatakan bahwa metode TwoStep Clustering cocok pada kasus penelitiannya. Metode TwoStep menggunakan data bertipe kontinu dan kategorik selain itu juga dapat menemukan jumlah cluster yang optimal. Kasus penelitiannya adalah mengidentifikasi profile customer bank.
Dengan menggunakan metode TwoStep clustering dapat mengelompokkan dataset menjadi tiga profil pelanggan. Kelompok cluster terbesar berisi pelanggan yang terampil, yang tujuan mengambil pinjamannya adalah untuk pendidikan atau bisnis. Kelompok klaster kedua terdiri atas orang-orang yang mempunyai real estat, tetapi kebanyakan menganggur, yang meminta pinjaman untuk mengadakan pelatihan ulang atau untuk barang-barang rumah tangga. Klaster ketiga adalah orang-orang dengan karakteristik tidak dikenal, yang membuat permintaan pinjaman untuk mobil atau televisi dan kemudian untuk pendidikan [5] Penggunaan TwoStep clustering juga dapat digunakan pada data campuran seperti pada [6].

Cho dan Kim mengadakan penelitian untuk mengevaluasi kinerja empat metode pengelompokan yaitu metode clustering Ward's variance minimum, metode $\mathrm{K}$ means clustering, jaringan Kohonen, dan algoritma TwoStep clustering. Metode TwoStep Clustering memberikan kinerja yang terbaik dalam hal kesalahan dalam-kelompok. Keempat cluster yang diperoleh dari metode TwoStep Clustering adalah banyak cluster yang dapat diterima secara optimal dan nyata. Skema jalan raya berdasarkan prosedur Highway Characteristic Classification (HCC) adalah empat jenis area jalan yang dikelompokkan sebagai perkotaan, pinggiran kota, pedesaan, dan daerah rekreasi [7].

Trpkova dan Tevdovski menggunakan TwoStep Clustering untuk segmentasi perusahaan di Makedonia. Setiap tahun, Central Register dari Republik Makedonia dan Pusat Bisnis Euro - Makedonia menyajikan publikasi dan mengungkapkan 200 perusahaan terbesar dan paling sukses di Makedonia.

Analisis ini berhasil menciptakan empat cluster berbagai jenis perusahaan di pasar Makedonia. Jenis pertama paling mewakili perusahaan yang sukses dengan pendapatan dan pertumbuhan stabil yang sangat tinggi. Perusahaan Ini berasal dari industri seperti komunikasi, listrik dan manufaktur, dan menyediakan lapangan kerja yang signifikan bagi angkatan kerja. Tipe kedua mewakili perusahaan dengan pendapatan yang relatif lebih kecil dibandingkan dengan tipe pertama, namun lebih tinggi dari rata-rata negara. Ini semua adalah perusahaan manufaktur dengan pertumbuhan yang stabil. Kelompok ketiga memiliki pendapatan yang sedikit lebih kecil daripada kelompok kedua, tetapi perbedaannya adalah bahwa klaster ini mewakili perusahaan dengan tingkat pertumbuhan pendapatan tinggi, dan mewakili perkembangan perusahaan dengan potensi signifikan. Ini adalah perusahaan yang sebagian besar menyediakan layanan, perusahaan yang menyediakan telekomunikasi dan transportasi, dan juga beberapa perusahaan dari industri lain. Sedangkan klaster terakhir mewakili perusahaan terkecil dari 200 perusahaan yang dianalisis [8].

Pada penelitian [9] dilakukan penelitian cluster dengan metode TwoStep pada 29 kejahatan serius yang dilaporkan di 1.119 kantor polisi di seluruh Afrika selatan untuk tahun anggaran 2009/2010. Dengan menggunakan metode ini pada set tersebut, maka dihasilkan tiga profil secara 
otomatis diidentifikasi sesuai dengan nilai AIC dan BIC. Profil terpenting berisi tiga belas variabel dengan bobot antara $100 \%$ dan $50 \%$. Ini mungkin dianggap sebagai kejahatan yang paling mendominasi di Afrika selatan. Profil ketiga berisi empat variabel yang paling tidak berbahaya yang berkontribusi tidak lebih dari 20\% terhadap kejahatan. Sisa dari dua puluh sembilan kejahatan yang ada merupakan komposisi pembentuk profile klaster kedua [9].

Penelitian [10] membuat cluster dengan metode TwoStep terhadap pembeli mobil baru di India dilakukan untuk mengidentifikasi taksonomi perilaku pencarian mobil yang menggunakan variabel kepribadian dan situasional, selain dari sumber informasi lain. Ada empat kelompok karakteristik pencari mobil berbeda yang ditemukan yaitu pencari sedang yang luas (broad moderate searchers), pencari sangat berat (intense heavy searchers), pencari luas rendah (low broad searchers), dan pencari rendah (low searchers). Dengan temuan itu, maka dealer dapat mengidentifikasi anggota masing-masing segmen dengan mengukur variabel yang ada, dan kemudian dapat merancang strategi komunikasi yang sesuai untuk masing-masing ke empat kelompok pencari mobil tersebut [10].

Penelitian [11] membuat klaster mahasiswa berdasarkan proses atau metode belajar mereka. Hal ini menyebabkan karakteristik proses belajar mahasiswa dapat diketahui. Klaster prestasi akademik menghasilkan jenis klaster tinggi, cukup tinggi, rendah dan sangat rendah. Metode clustering yang digunakan dalam riset tersebut adalah TwoStep Cluster Analysis (TCA). Riset tersebut menunjukan bahwa mahasiswa dapat terclustering ke dalam dua kelompok utama. Kelompok pertama terdiri dari $100 \%$ mahasiswa dengan prestasi akademik sangat tinggi, 82,6\% tinggi, $62,7 \%$ cukup tinggi, dan kelompok kedua $18,5 \%$ rendah serta $0 \%$ sangat rendah.

Kelompok pertama memang memiliki kebiasaan cara belajar yang sangat baik dari semua variabel proses belajar, terkhusus variabel sifat rajin dalam mengerjakan soal-soal dan latihan saat kuliah (X64) dan rajin untuk mengulang kembali materi kuliah (X51), namun kelompok kedua adalah kebalikannya. Variabel yang paling mirip pada kedua kelompok tersebut adalah kesadaran mahasiswa untuk belajar (X11) dan kepercayaan mahasiswa terhadap kemampuan mereka sendiri (X12). Mahasiswa angatan baru sangat dominan berada pada kelompok pertama, sedangkan mahasiswa angkatan lama lebih masuk ke dalam kelompok kedua [11].

Penelitian [12] mengadakan analisis terhadap menu engineering Usaha Mikro Kecil dan Menengah (UMKM) di Salatiga pada di bidang kuliner menggunakan metode Two-Step Clustering. Riset ini akhirnya dapat memperoleh cluster secara wajar sesuai dengan kumpulan data menu yang tersedia sehingga dapat ditemukan jumlah cluster yang terbaik. Melalui menggunakan indikator Schwarz's Bayesian Information Criterion (BIC) dihasilkan jumlah 4 bauh cluster optimal. Tujuan dan manfaat dari riset tersebut akan digunakan sebagai rekomendasi kebijakan bagi pemilik UMKM agar dapat meningkatkan pendapatan dari perusahaan tersebut [12].

Berdasarkan uraian dari paragraf-paragraf sebelumnya, dapat dikatakan bahwa metode TwoStep Clustering telah diaplikasikan pada berbagai bidang yang cukup luas, sebagai contoh: bidang ekonomi [8], bidang keamanan dan kependudukan [9], bidang marketing [10], kegiatan belajar mengajar [11], bidang teknologi informasi yang berfokus pada user interface design [12]. Pada tulisan ini, penulis menerapkan metode TwoStep clustering pada bidang pendidikan, yaitu untuk melihat karakteristik mahasiswa terhadap beberapa faktor dan melihat hasil klaster yang terbentuk pada setiap angkatan. Peneltian ini termasuk penelitian aplikatif yang mempunyai kontribusi berupa dukungan dalam pertimbangan terhadap suatu keputusan atau kebijakan di dalam organisasi. Bila penelitianpenelitian di atas dilakukan pada satu waktu tertentu, maka pada penelitian ini juga akan dapat dilihat perubahan pembentukan cluster-cluster selama beberapa waktu (dua belas tahun) yang kemudian dapat dianalisis pada bab Hasil dan Pembahasan.

\section{B. Landasan Teori}

1) Proses Clustering: pada hakekatnya proses clustering adalah proses pengelompokan berdasarkan beberapa variabel yang dipilih oleh peneliti. Setelah proses clustering maka dihasikan klaster-klaster dengan ciri-ciri tertentu. Ciri-ciri ini timbul tanpa adanya campur tangan dari peneliti, dengan kata lain yaitu biarlah "data berbicara dari dirinya sendiri". Dasar dari clustering adalah similaritas/disimilaritas antara satu objek dengan objek lainnya. Adanya klaster-klaster dengan ciri tertentu yang berbeda ataupun yang mencolok ini, akhirnya akan menghasilkan klasifikasi.

Beberapa contoh clustering, misalnya dalam pemasaran, clustering digunakan untuk memilah pasar. Contoh lainnya adalah termasuk clustering perusahaan sesuai dengan struktur organisasi, teknologi dan tipe mereka . Dalam psikologi, clustering digunakan untuk menemukan tipe kepribadian seseorang berdasarkan kuesioner. Dalam arkeologi, hal ini dapat diterapkan untuk clustering objek seni dalam kurun waktu yang berbeda . Cabang ilmiah lain yang menggunakan analisis cluster adalah kedokteran, sosiologi, linguistik dan biologi. Dalam setiap kasus, sampel objek yang heterogen dianalisis dengan tujuan untuk mengidentifikasi dan mendapatkan subkelompok yang homogen [15]. Biasanya clustering sering juga disebut dengan unsupervised classification [16]. Metode clustering yang sering digunakan adalah K-Means seperti yang digunakan pada [17] pada bidang kesehatan dan [18] pada bidang pendidikan.

2) Metode TwoStep Clustering :Metode analisis cluster merupakan salah satu jenis analisis statistik multivariate yang dipergunakan terhadap $\mathrm{N}$ buah data yang masingmasing memiliki $p$ variabel dan akan dimasukan ke dalam sejumlah $K$ klaster. Data yang masuk kedalam satu kelompok klaster memiliki kesamaan karakteristik yang lebih mirip dibandingkan dengan data yang masuk kedalam 
kelompok cluster lain [15]. Sesuai dengan penelitian [19], terdapat dua metode dalam analisis klaster yaitu berhirarki (hierarchical clustering method) dan metode tak berhirarki (non hierarchical clustering method). Metode berhirarki digunakan apabila belum terdapat informasi jumlah klaster yang akan dibentuk, sedangkan metode tak berhierarki bertujuan untuk mengelompokkan data ke dalam $K$ cluster $(\mathrm{K}<\mathrm{N})$ dimana nilai $K$ telah ditentukan sejak awal.

Pada analisis klaster, terdapat beberapa jenis ukuran jarak (metric) yang digunakan pada setiap pasang data yang akan dikelompokkan. Beberapa metode pengukuran jarak antar dua data adalah:

\section{a. Euclidean Distance}

Euclidean Distance merupakan jarak yang umum digunakan apabila semua variabelnya bersifat kontinu. Dalam metode ini, pengukuran jarak dilakukan dengan menghitung akar kuadrat dari penjumlahan kuadrat selisih dari nilai masing-masing variabel. Euclidean Distance menggunakan rumus sebagai berikut:

$$
d_{i, j}=\sqrt{\sum_{k=1}^{p}\left(x_{i k}-x_{j k}\right)^{2}}
$$

Dimana:

$d_{i, j}=$ jarak antara data $\mathrm{i}$ dengan data $\mathrm{j}$

$x_{i k}=$ nilai data $i$ pada variabel ke- $\mathrm{k}$

$x_{j k}=$ nilai data $\mathrm{j}$ pada variabel ke- $\mathrm{k}$

$\mathrm{p}$ = banyaknya variabel yang digunakan

\section{b. Log-Likelihood Distance}

Log-Likelihood Distance ini digunakan pada variabel yang bersifat kontinu dan kategorikal. Jarak antara cluster $\mathrm{j}$ dengan cluster s dapat dirumuskan sebagai berikut [6]:

Dimana:

$$
d(j, s)=\xi_{j}+\xi_{s}-\xi_{(j s)}
$$

$$
\begin{aligned}
& \xi_{j}=-N\left(\sum_{k=1}^{K^{A}} \frac{1}{2} \log \left(\widehat{\sigma_{k}^{2}}+\widehat{\sigma_{j k}^{2}}\right)-\sum_{k=1}^{K^{B}} \sum_{l=1}^{L_{k}} \frac{N_{j k l}}{N_{j}} \log \left(\frac{N_{j k l}}{N_{j}}\right)\right) \\
& \xi_{s}=-N\left(\sum_{k=1}^{K^{A}} \frac{1}{2} \log \left(\widehat{\sigma_{k}^{2}}+\widehat{\sigma_{s k}^{2}}\right)-\sum_{k=1}^{K^{B}} \sum_{l=1}^{L_{k}} \frac{N_{s k l}}{N_{j}} \log \left(\frac{N_{s k l}}{N_{j}}\right)\right) \\
& \xi_{(j s)}=-N\left(\sum_{k=1}^{K^{A}} \frac{1}{2} \log \left(\widehat{\sigma_{k}^{2}}+\widehat{\sigma_{(J s) k}^{2}}\right)-\sum_{k=1}^{K^{B}} \sum_{l=1}^{L_{k}} \frac{N_{(j s) k l}}{N_{j}} \log \left(\frac{N_{(j s k l)}}{N_{j}}\right)\right)
\end{aligned}
$$

Keterangan:

$\mathrm{N}=$ banyak seluruh data

$\mathrm{N}_{\mathrm{j}}=$ banyak data yang berada dalam klaster $\mathrm{j}$

$\mathrm{N}_{\mathrm{jkl}}=$ banyak data yang terdapat di klaster $\mathrm{j}$ untuk variabel kategorikal ke- $\mathrm{k}$ dengan kategori ke- 1

$\widehat{\sigma_{k}^{2}}=$ perkiraan varian pada variabel kontinu ke- $\mathrm{k}$ untuk

keseluruhan data

$\widehat{\sigma_{j k}^{2}}=$ perkiraan varians pada variabel kontinu ke- $\mathrm{k}$ untuk

keseluruhan data dalam cluster $\mathrm{j}$

$\mathrm{K}^{\mathrm{A}}$ = banyaknya variabel kontinu

$\mathrm{K}^{\mathrm{B}}$ = banyaknya variabel kategorikal

$\mathrm{L}_{\mathrm{k}}=$ banyaknya kategori untuk variabel kategorikal ke- $\mathrm{k}$

\section{c. Chi-Square Distance}

Chi-square distance menghitung antara data dalam Euclidean distance yang terboboti menggunakan invers proporsi rata-rata sebagai bobot. Misalnya $\mathrm{c}_{\mathrm{j}}$ menunjukkan elemen ke-j dari rata-rata data, dimana rata-rata data merupakan hasil proporsi variabel dalam seluruh data. Chi-
Square distance, dinotasikan sebagai $\chi$, antara dua objek dengan data $\boldsymbol{x}=\left[\begin{array}{lllll}x_{1} & x_{2} & x_{3} & \ldots & x_{j}\end{array}\right]$ dan $\boldsymbol{y}=$ $\left[\begin{array}{lllll}y_{1} & y_{2} & y_{3} & \ldots & y_{j}\end{array}\right]$ didefinisikan sebagai :

$$
\chi_{x, y}=\sqrt{\sum_{j=1}^{J} \frac{1}{c_{j}}\left(x_{j}-y_{j}\right)^{2}}
$$

Metode Two Step clustering merupakan metode yang didesain untuk menangani clustering yang mempunyai variabel campuran yaitu variabel kontinu dan variabel kategorikal. Jarak antara dua klaster merupakan jarak antar pusat dari masing-masing klaster. Pusat dari suatu klaster adalah vektor rata-rata dari masing-masing variabel mereka. Jarak yang digunakan dalam metode two step clustering adalah Log-Likelihood distance dan Euclidean distance. Prosedur clustering dengan metode two step clusterig memiliki dua tahapan utama yaitu tahap preclustering (clustering awal) data ke dalam subcluster-subcluster kecil dan tahap clustering akhir [6]. Penjelasannya dapat dilihat pada bagian berikutnya.

\section{d. Tahap Clustering Awal (Preclustering)}

Pada tahap ini data diamati satu persatu secara sekuensial, berdasarkan ukuran jarak yang telah ditentukan sebelunnya. Dari tahao ini dihasilkan dua kemungkinan, apakah data tersebut masuk dalam klaster yang telah terbentuk atau harus membentuk lagi klaster baru. Pada tahap ini dapat divisualisasikan dengan adanya pembuatan Cluster Feature (CF) Tree.

Diberikan $\mathrm{N}$ titik data $d$ dimensi pada suatu klaster dimana $i=1,2, \ldots, \mathrm{N}$. Vektor clustering feature dari klaster didefinisikan sebagai quadriple: $\mathrm{CF}=(\mathrm{N}, \mathrm{M}, \mathrm{V}, \mathrm{K})$ dimana

$\mathrm{N}$ merupakan banyaknya data pada klaster,

M merupakan rata-rata dari variabel kontinu dari $\mathrm{N}$ data,

$\mathrm{V}$ merupakan variansi dari setiap variabel kontinu pada $\mathrm{N}$ data,

K merupakan banyaknya level pada setiap variabel kategorikal. CF-tree merupakan pohon dengan keseimbangan tinggi dengan dua parameter yaitu branching factor $(\mathrm{B})$ dan threshold $(\mathrm{T})$.

CF-tree terdiri dari beberapa node dan masing-masing node berisi individu data (entries) dari cluster awal. Tingkatan daun entri yang terdapat pada cabang merepresentasikan anak klaster (subcluster-subcluster). Prosedur CF-tree dilakukan dengan memilih satu objek awal secara acak yang akan diukur jaraknya satu persatu dengan data lainnya menggunakan ukuran jarak yang telah ditentukan. Jika besarnya jarak terletak pada suatu threshold tertentu, maka data akan menjadi anggota anak klaster. Jika besarnya jarak terletak di luar threshold, maka data tersebut masuk ke dalam klaster yang telah dibentuk atau akan menjadi calon daun entri yang baru. Gambar 1 merupakan ilustrasi proses pembentukan CF-tree. 

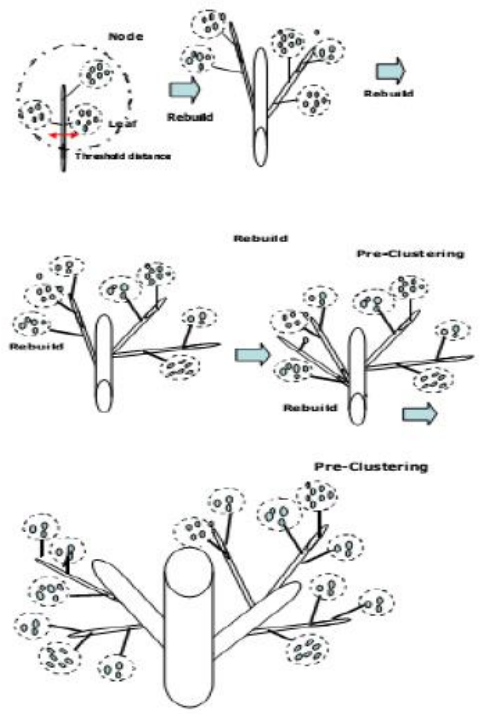

Gambar 1. Proses pembentukan CF-tree [13]

Jika dalam kasus data terdapat outlier, maka ketika CFtree dibentuk, akan diperiksa apakah dapat dimasukkan dalam cluster yang sudah terbentuk tanpa harus membentuk CF-tree baru atau tidak. Untuk mendeteksi ada tidaknya outlier dilakukan perhitungan Log-Likelihood distance. Jika terdapat jarak terbesar antar cluster yang melebihi titik kritis $\mathrm{C}$, yaitu:

dengan:

$$
\mathrm{C}=\log (\mathrm{V})
$$

dan

$$
V=\prod_{k} R_{k} \prod_{m} L_{m}
$$

$\mathrm{R}_{\mathrm{k}}=$ range dari variabel kontinu ke- $\mathrm{k}$

$\mathrm{L}_{\mathrm{m}}=$ banyaknya kategori untuk variabel kategorik ke- $\mathrm{m}$.

Pada Euclidean distance, data yang memuat outlier memiliki prosedur yang sama dengan Log-Likelihood distance. Dikatakan outlier jika Euclidean distance terbesar antara klaster tersebut lebih besar dari titik kritis C, dengan rumus $\mathrm{C}$ sebagai berikut [6]:

$$
C=2\left(\sum_{i=1}^{K^{A}} \frac{\widehat{\sigma_{k l}^{2}}}{K^{A}}\right)^{1 / 2}
$$

dengan :

$\mathrm{R}_{\mathrm{k}}=$ jangkauan dari variabel kontinu ke- $\mathrm{k}$

$K^{A}=$ banyaknya variabel kontinu

$\widehat{\sigma_{k l}^{2}}=$ perkiraan variansi untuk variabel kontinu ke- 1 dalam cluster $\mathrm{k}$.

Pembentukan CF-tree terdiri dari dua tahap. Tahap pertama yaitu tahap penyisipan (inserting) dan tahap kedua adalah tahap pembentukan kembali (rebuilding). Pada tahap inserting, secara random akan dipilih satu data kemudian dilakukan pengukuran jarak dengan data lain. Jika jarak tersebut kurang dari jarak maksimum, maka data tersebut dimasukkan ke dalam satu klaster. Tetapi jika jarak tersebut melebihi jarak maksimum, maka data tersebut dianggap outlier, demikian seterusnya untuk data selanjutnya.

Tahap rebuilding merupakan tahap dimana data yang dianggap outlier, akan dibuat suatu cluster yang baru. Jika CF-tree semakin banyak hingga melewati batas threshold maksimum yang telah ditetapkan, maka threshold jarak maksimum harus dinaikan sehingga dapat memasukkan lebih banyak data lagi. Penambahan jarak ini dapat menyebabkan objek-objek yang tadinya berasal dari cluster yang berbeda akan bergabung menjadi satu cluster $\mathrm{CF}$, sehingga menghasilkan CF-tree yang berukuran lebih kecil dari semula.

\section{e. Clustering Akhir (PostClustering)}

Pada tahap ini, hasil dari CF-tree dikelompokkan dengan metode agglomerative (salah satu analisis cluster berhierarki ). Untuk menghitung banyaknya cluster dapat dilakukan dengan dua tahapan, yang pertama adalah menghitung Schwarz's Bayesian Criterion (BIC) atau Akaike's Information Criterion (AIC) untuk tiap klaster. Suatu cluster J mempunyai bentuk BIC dan AIC adalah sebagai berikut [6]:

$$
\begin{aligned}
& B I C(J)=-2 \sum_{j=1}^{J} \xi_{j}+m_{j} \log (N) \\
& A I C(J)=-2 \sum_{j=1}^{J} \xi_{j}+2 m_{j}
\end{aligned}
$$

dengan:

$$
\begin{aligned}
& m_{j}=J\left\{2 K^{A}+\sum_{k=1}^{K^{B}}\left(L_{k}-1\right)\right\} \\
& \xi_{j}=-N\left(\sum_{k=1}^{K^{A}} \frac{1}{2} \log \left(\widehat{\sigma_{k}^{2}}+\widehat{\sigma_{J k}^{2}}\right)-\sum_{k=1}^{K^{B}} \sum_{l=1}^{L_{k}} \frac{N_{j k l}}{N_{j}} \log \left(\frac{N_{j k l}}{N_{j}}\right)\right)
\end{aligned}
$$

Solusi banyaknya cluster yang optimal adalah yang memiliki nilai BIC terkecil, tetapi ada beberapa kasus dalam clustering dimana BIC akan terus meningkat nilainya bila jumlah cluster semakin meningkat. Maka dalam situasi tersebut, ratio BIC changes (rasio perubahan BIC) dan ratio of distance measure changes (rasio perubahan jarak) digunakan untuk mengidentifikasi solusi banyaknya klaster optimal. Solusi untuk banyaknya klaster optimal akan memiliki ratio BIC changes dan ratio distance measure yang besar.

Jumlah klaster yang terbentuk dapat diketahui dengan menggunakan perbandingan antar jarak untuk klaster, dengan rumus sebagai berikut [6]:

$$
\begin{aligned}
& R(\mathrm{k})=d_{\mathrm{k}-1} / d_{\mathrm{k}} \\
& d_{\mathrm{k}}=l_{\mathrm{k}-1}-l_{\mathrm{k}}
\end{aligned}
$$

dengan:

2

$l_{v}=\left(r_{v} \log n-B I C_{v}\right) / 2$, atau $l_{v}=\left(2 r_{v}-A I C_{v}\right) /$

$\mathrm{v}=\mathrm{k}, \mathrm{k}-1$

$d_{\mathrm{k}-1}=$ jarak jika k klaster digabungkan dengan k-1 klaster $R(\mathrm{k})=$ rasio perubahan jarak.

Penentuan variabel yang berpengaruh adalah dengan melihat nilai $t$ dengan rumus sebagai berikut :

$$
t=\frac{\widehat{\mu_{k}}-\widehat{\mu}_{j k}}{\widehat{\sigma}_{j k} / \sqrt{N_{k}}}
$$

dengan:

$\widehat{\mu_{k}}:$ mean variabel numeric ke-k

$\hat{\mu}_{j k}$ : mean variabel numeric ke-k kelompok ke-j

$\hat{\sigma}_{j k}$ : standar deviasi variabel numerik ke-k pada klaster $\mathrm{ke}-\mathrm{j}$

$N_{k}$ : jumlah observasi pada variabel numerik ke-k dengan:

dan chi-square dengan rumus sebagai berikut 


$$
\chi^{2}=\sum_{l=1}^{l_{k}}\left(\frac{N_{j k l}-N_{k l}}{N_{k l}}\right)^{2}
$$

dengan:

$N_{j k l}$ : jumlah observasi pada klaster ke-j untuk variabel kategorik ke-k dengan kategori ke- $l$

$N_{k l}$ : jumlah observasi pada klaster untuk variabel kategori ke-k dengan kategori ke- $l$

$l_{k}$ : jumlah kategori untuk variabel kategorik ke-k

\section{Metodologi Penelitian}

Metodologi penelitian yang digunakan untuk proses ini memiliki beberapa tahap, yaitu :

1. Mengumpulkan data mahasiswa selama 12 tahun akademik, yaitu mahasiswa tahun akademik 2008 tahun akademik 2019. Data mahasiswa ini diperoleh dari Pusat Pelayanan Informasi dan Intranet Kampus (PUSPINDIKA) UKDW . Data ini meliputi Nomor Induk Mahasiswa (NIM), kategori SMA, status SMA, lokasi SMA, Indeks Prestasi Semester 1 (IPS1) dan hasil nilai Tes Kemampuan Akademik (TKA) .

2. Membuat transformasi dari data tipe string menjadi tipe numerik. Data kategori SMA ( SMA menjadi "1" dan SMK menjadi "2") , status SMA (Negeri menjadi "1" dan Swasta menjadi “2”), lokasi SMA ( Jawa menjadi "1" dan Luar Jawa menjadi "2") dan level bahasa Inggris ( level_1 menjadi "1", level_2 menjadi "2" , level_3 menjadi "3" dan ESP menjadi "4") .

3. Mengelompokan data mahasiswa FTI yang melalui Jalur Prestasi (JP) dan Non Jalur Prestasi (NJP) . Jalur NJP ini yang biasa disebut jalur reguler. Calon mahasiswa pada JP tidak mengikuti Tes Kemampuan Akademik (TKA) . Sedangkan pada calon mahasiswa NJP harus mengikuti TKA yang terdiri dari tes kemampuan Numerik, Verbal, Spasial dan Analogi.

4. Melakukan TwoStep Clustering terhadap 12 angkatan mahasiswa FTI yang termasuk JP .

5. Pengelompokan dengan TWoStep Clustering tersebut dengan menggunakan 5 variabel, sebagai berikut

- $\mathrm{X}_{1}$ adalah status SMA

- $\mathrm{X}_{2}$ adalah lokasi SMA

- $\mathrm{X}_{3}$ adalah kategori SMA

- $\mathrm{X}_{4}$ adalah level bahasa Inggris
- $\mathrm{X}_{5}$ adalah IP semester 1

6. Hasil dari TwoStep Clustering ini adalah tiap angkatan akan terbentuk menjadi beberapa klaster

7. Melakukan TwoStep Clustering terhadap 12 angkatan mahasiswa FTI yang masuk NJP .

8. Pengelompokan dengan TwoStep Clustering tersebut dengan menggunakan 10 variabel, sebagai berikut

- $\mathrm{X}_{1}$ adalah status SMA

- $\mathrm{X}_{2}$ adalah lokasi SMA

- $\mathrm{X}_{3}$ adalah kategori SMA

- $\mathrm{X}_{4}$ adalah level bahasa Inggris

- $\mathrm{X}_{5}$ adalah IP semester 1

- $\mathrm{X}_{7}$ adalah nilai Numerik

- $\mathrm{X}_{8}$ adalah nilai Verbal

- $\mathrm{X}_{9}$ adalah nilai Spatial

- $\mathrm{X}_{10}$ adalah nilai Analogi

Hasil dari TwoStep Clustering ini adalah tiap angkatan akan terbentuk menjadi beberapa klaster

9. Melihat karakteristik centroid-centroid dari 12 angkatan untuk mahasiswa JP

10. Melihat karakteristik centroid-centroid dari 12 angkatan untuk mahasiswa NJP.

\section{IV.HASIL DAN PEMBAHASAN}

Dari pengolahan data angkatan 2008 sampai dengan 2018 dengan metode TwoStep Clustering dapat dilihat pada bagian ini.

\section{A. Hasil Penelitian}

Hasil dari proses TwoStep Clustering untuk mahasiswa jalur prestasi dapat dilihat pada Tabel 1 dan Tabel 2. Adapun keterangan simbol variabel tersebut adalah: $\mathrm{x}_{1}$ adalah status SMA, $\mathrm{x}_{2}$ adalah lokasi SMA, $\mathrm{x}_{3}$ adalah kategori SMA , $\mathrm{x}_{4}$ adalah level bahasa Inggris, $\mathrm{x}_{5}$ adalah IP Semester 1 dan $\mathrm{x}_{6}$ adalah banyaknya anggota klaster.

Berdasarkan Schwarz's Bayesian Criterion (BIC) yang kecil dan Rasio Distance Measure $(\mathrm{R}(\mathrm{k}))$ yang besar maka dapat ditentukan jumlah klaster yang cocok untuk setiap model. Hasil penentuannya dapat dilihat pada Tabel 1 dan Tabel 3. Sedangkan untuk non jalur prestasi dapat dilihat pada Tabel 2 dan Tabel 4. 
TABEL I

INFORMASI RASIO DISTANCE MEASURE MAHASISWA JALUR PRESTASI (JP) - ANGKATAN 2008 SD 2019 UNTUK BERBAGAi J KLASTER

\begin{tabular}{|l|c|c|c|c|c|c|c|c|c|c|c|c|}
\hline & \multicolumn{10}{c|}{ Rasio Distance Measure untuk j = 2 sd 13 } \\
\hline $\begin{array}{c}\text { Angkata } \\
\mathbf{n}\end{array}$ & $\mathbf{2}$ & $\mathbf{3}$ & $\mathbf{4}$ & $\mathbf{5}$ & $\mathbf{6}$ & $\mathbf{7}$ & $\mathbf{8}$ & $\mathbf{9}$ & $\mathbf{1 0}$ & $\mathbf{1 1}$ & $\mathbf{1 2}$ & $\mathbf{1 3}$ \\
\hline 2008 & 1,600 & 1,074 & 1,521 & 1,231 & 1,076 & 1,056 & 1,988 & 1,033 & 1,162 & 1,004 & 1,572 & 1,094 \\
\hline 2009 & 2,182 & 1,640 & 1,274 & 3,979 & 5,151 & 4,173 & 3,230 & 6,221 & 35,969 & & & \\
\hline 2010 & 1,589 & 1,635 & 1,383 & 1,008 & 1,643 & 1,373 & 1,050 & 1,075 & 2,202 & 1,014 & 1,161 & 1,014 \\
\hline 2011 & 1,569 & 1,030 & 1,457 & 1,405 & 1,237 & 1,075 & 1,305 & 1,287 & 1,100 & 1,234 & 1,072 & 1,284 \\
\hline 2012 & 1,685 & 1,186 & 1,385 & 1,269 & 1,850 & 1,017 & 1,096 & 1,105 & 1,071 & 1,273 & 1,279 & 1,108 \\
\hline 2013 & 1,669 & 1,280 & 1,621 & 1,189 & 1,320 & 1,402 & 1,816 & 1,014 & 1,255 & 1,157 & 1,087 & 1,032 \\
\hline 2014 & 1,715 & 1,286 & 1,789 & 1,016 & 1,133 & 1,065 & 1,819 & 1,024 & 1,142 & 1,104 & 1,098 & 1,208 \\
\hline 2015 & 2,508 & 1,436 & 1,600 & 1,033 & 1,667 & 1,036 & 1,064 & 1,454 & 1,025 & 1,015 & 1,488 & 1,678 \\
\hline 2016 & 1,318 & 1,272 & 1,396 & 1,185 & 1,271 & 1,109 & 1,095 & 1,081 & 1,329 & 1,274 & 1,035 & 1,236 \\
\hline 2017 & 1,867 & 1,179 & 1,202 & 1,241 & 1,347 & 1,072 & 1,149 & 1,037 & 1,214 & 1,109 & 1,389 & 1,072 \\
\hline 2018 & 1,701 & 1,132 & 1,194 & 1,110 & 1,461 & 1,148 & 1,146 & 1,037 & 1,243 & 1,206 & 1,003 & 1,158 \\
\hline 2019 & 1,792 & 1,512 & 1,126 & 1,147 & 1,377 & 1,086 & 1,108 & 1,319 & 1,083 & 1,146 & 1,071 & 1,314 \\
\hline
\end{tabular}

TABEL III

INFORMASI RASIO DisTANCE MEASURE MAHASISWA NON JALUR PRESTASI (NJP) ANGKATAN 2008 SD 2019 UNTUK BERBAGAI J KLASTER

\begin{tabular}{|l|c|c|c|c|c|c|c|c|c|c|c|c|}
\hline & \multicolumn{10}{|c|}{ Rasio Distance Measure untuk j = 2 sd 13 } \\
\hline Angkatan & $\mathbf{2}$ & $\mathbf{3}$ & $\mathbf{4}$ & $\mathbf{5}$ & $\mathbf{6}$ & $\mathbf{7}$ & $\mathbf{8}$ & $\mathbf{9}$ & $\mathbf{1 0}$ & $\mathbf{1 1}$ & $\mathbf{1 2}$ & $\mathbf{1 3}$ \\
\hline 2008 & 1,193 & 1,266 & 1,254 & 1,245 & 1,081 & 1,738 & 1,085 & 1,063 & 1,124 & 1,010 & 1,323 & 1,058 \\
\hline 2009 & 1,876 & 1,579 & 1.038 & 1,306 & 1,081 & 1,084 & 1,774 & 1,040 & 1,132 & 1,129 & 1,092 & 1,005 \\
\hline 2010 & 1,494 & 1,494 & 1,221 & 1,352 & 1,032 & 1,271 & 1,099 & 1,211 & 1,326 & 1,118 & 1,140 & 1,182 \\
\hline 2011 & 2,082 & 1,112 & 1,278 & 1,212 & 1,653 & 1,007 & 1,114 & 1,118 & 1,040 & 1,071 & 1,062 & 1,074 \\
\hline 2012 & 1,848 & 1,476 & 1,021 & 1,301 & 1,273 & 1,241 & 1,015 & 1,098 & 1,136 & 1,154 & 1,062 & 1,202 \\
\hline 2013 & 1,147 & 1,455 & 1,278 & 1,012 & 1,253 & 1,150 & 1,503 & 1,009 & 1,340 & 1,011 & 1,024 & 1,015 \\
\hline 2014 & 2,575 & 1,267 & 1,123 & 1,253 & 1,011 & 1,351 & 1,261 & 1,234 & 1,079 & 1,121 & 1,139 & 1,061 \\
\hline 2015 & 1,203 & 1,144 & 1,921 & 1,058 & 1,102 & 1,613 & 1,013 & 1,141 & 1,232 & 1,064 & 1,268 & 1,094 \\
\hline 2016 & 2,527 & 1,090 & 1,194 & 1,280 & 1,227 & 1,100 & 1,378 & 1,176 & 1,012 & 1,221 & 1,092 & 1,115 \\
\hline 2017 & 1,251 & 1,491 & 1,077 & 1,472 & 1,354 & 1,151 & 1,248 & 1,187 & 1,017 & 1,065 & 1,268 & 1,075 \\
\hline 2018 & 1,774 & 1,381 & 1,055 & 1,018 & 1,272 & 1,168 & 1,230 & 1,066 & 1,184 & 1,059 & 1,217 & 1,010 \\
\hline 2019 & 1,728 & 1,189 & 1,258 & 1,091 & 1,324 & 1,178 & 1,359 & 1,012 & 1,131 & 1,127 & 1,130 & 1,066 \\
\hline
\end{tabular}

TABEL IIIII

INFORMASI BANYAK KLASTER YANG COCOK PADA MAHASISWA JALUR PRESTASI (JP) ANGKATAN 2008 SD 2019

\begin{tabular}{|c|c|c|}
\hline Angkatan & $\begin{array}{l}\text { Banyak } \\
\text { klaster }\end{array}$ & Alasan pemilihan banyak klaster \\
\hline 2008 & 4 & $\begin{array}{l}\text { Nilai } R(4) \text { terbesar dan karena nilai } \mathrm{BIC}(4) \\
\text { terkecil dari } \operatorname{BIC}(2)=350,165, \operatorname{BIC}(4)= \\
315,395, \quad \operatorname{BIC}(8)=342,844\end{array}$ \\
\hline 2009 & 2 & $\begin{array}{l}\text { Nilai } \mathrm{R}(2) \text { terbesar dan karena nilai } \mathrm{BIC}(2) \\
=61,743 \text { dan yang lain lebih besar dari } \\
\text { BIC(2) }\end{array}$ \\
\hline 2010 & 3 & $\begin{array}{l}\text { Nilai } R(3)=1,635 \text { terbesar dan karena nilai } \\
\text { BIC(3) terkecil dari BIC yang lain }\end{array}$ \\
\hline 2011 & 3 & $\begin{array}{l}\text { Nilai } R(3)=1,030 \text { terbesar dan karena nilai } \\
\text { BIC(3) terkecil dari BIC yang lain }\end{array}$ \\
\hline 2012 & 6 & Nilai $\mathrm{R}(6)=1,850$ terbesar \\
\hline 2013 & 4 & $\begin{array}{l}\text { Nilai } R(4)=1,621 \text { terbesar dan karena nilai } \\
\text { BIC(4) terkecil dari BIC yang lain }\end{array}$ \\
\hline 2014 & 4 & $\begin{array}{l}\text { Nilai } R(4)=1,789 \text { terbesar dan karena nilai } \\
\text { BIC(4) terkecil dari BIC yang lain }\end{array}$ \\
\hline 2015 & 2 & $\begin{array}{l}\text { Nilai } R(2)=2,508 \text { terbesar dan karena nilai } \\
\text { BIC }(2) \text { terkecil dari BIC yang lain }\end{array}$ \\
\hline 2016 & 4 & $\begin{array}{l}\text { Nilai } R(4)=1,396 \text { terbesar dan karena nilai } \\
\text { BIC(4) terkecil dari BIC yang lain }\end{array}$ \\
\hline 2017 & 2 & $\begin{array}{l}\text { Nilai } R(2)=1,867 \text { terbesar dan karena nilai } \\
\text { BIC }(2) \text { terkecil dari BIC yang lain }\end{array}$ \\
\hline 2018 & 2 & $\begin{array}{l}\text { Nilai } R(2)=1,701 \text { terbesar dan karena nilai } \\
\text { BIC }(2) \text { terkecil dari BIC yang lain }\end{array}$ \\
\hline 2019 & 2 & $\begin{array}{l}\text { Nilai } R(2)=1,792 \text { terbesar dan karena nilai } \\
\text { BIC(2) terkecil dari BIC yang lain }\end{array}$ \\
\hline
\end{tabular}

\section{TABEL IVV}

INFORMASI BANYAK KLASTER YANG COCOK PADA MAHASISWA NON JALUR PRESTASI (NJP) ANGKATAN 2008 SD 2019

\begin{tabular}{|l|l|l|}
\hline Angkatan & $\begin{array}{l}\text { Banyak } \\
\text { klaster }\end{array}$ & Alasan pemilihan banyak klaster \\
\hline 2008 & 7 & $\begin{array}{l}\text { Nilai } \mathrm{R}(4)=1,738 \text { terbesar dan karena } \\
\text { nilai BIC(4) terkecil dari BIC yang lain }\end{array}$ \\
\hline 2009 & 2 & $\begin{array}{l}\text { Nilai } \mathrm{R}(2)=1,876 \text { terbesar dan karena } \\
\text { nilai BIC(2)=61,743 dan yang lain lebih } \\
\text { besar dari BIC(2) }\end{array}$ \\
\hline 2010 & 3 & $\begin{array}{l}\text { Nilai } \mathrm{R}(3)=1,494 \text { terbesar dan karena } \\
\text { nilai BIC(3) terkecil dari BIC yang lain }\end{array}$ \\
\hline 2011 & 2 & $\begin{array}{l}\text { Nilai } \mathrm{R}(2)=2,082 \text { terbesar dan karena } \\
\text { nilai } \mathrm{BIC}(3) \text { terkecil dari BIC yang lain }\end{array}$ \\
\hline 2012 & 2 & Nilai $\mathrm{R}(2)=1,848$ terbesar \\
\hline 2013 & 3 & $\begin{array}{l}\text { Nilai } \mathrm{R}(3)=1,455 \text { terbesar dan karena } \\
\text { nilai } \mathrm{BIC}(3) \text { terkecil dari BIC yang lain }\end{array}$ \\
\hline 2014 & 4 & Nilai $\mathrm{R}(4)=2,575$ terbesar \\
\hline 2015 & 4 & Nilai $\mathrm{R}(4)=1,921$ terbesar \\
\hline 2016 & 2 & $\begin{array}{l}\text { Nilai } \mathrm{R}(2)=1,396 \text { terbesar dan karena } \\
\text { nilai } \mathrm{BIC}(4) \text { terkecil dari BIC yang lain }\end{array}$ \\
\hline 2017 & 3 & Nilai $\mathrm{R}(2)=2,527$ terbesar \\
\hline 2018 & 2 & Nilai $\mathrm{R}(2)=1,774$ terbesar \\
\hline 2019 & 2 & Nilai $\mathrm{R}(2)=1,728$ terbesar \\
\hline
\end{tabular}


TABEL V

INFORMASI KLASTER MAHASISWA JALUR PRESTASI (JP) ANGKATAN 2008 SD 2019

\begin{tabular}{|c|c|c|c|c|c|c|c|c|c|c|c|c|}
\hline \multirow{2}{*}{\begin{tabular}{|c|}
$\begin{array}{c}\text { Angka } \\
\tan \end{array}$ \\
\end{tabular}} & \multicolumn{2}{|c|}{$\mathbf{X}_{1}$} & \multicolumn{2}{|c|}{$\mathbf{X}_{2}$} & \multicolumn{2}{|c|}{$\mathbf{X}_{3}$} & \multicolumn{4}{|c|}{$\mathbf{X}_{4}$} & \multirow[t]{2}{*}{$\mathbf{X}_{5}$} & \multirow{2}{*}{$\begin{array}{l}X \\
6 \\
\end{array}$} \\
\hline & 1 & 2 & 1 & 2 & 1 & 2 & 1 & 2 & 3 & 4 & & \\
\hline 2008 & & & & & & & & & & & & 63 \\
\hline $\begin{array}{l}\text { Cluster } \\
1\end{array}$ & $\begin{array}{l}1 \\
0 \\
\end{array}$ & 7 & 1 & 4 & $\begin{array}{l}1 \\
7 \\
\end{array}$ & 0 & 0 & 0 & $\begin{array}{l}1 \\
7 \\
\end{array}$ & 0 & $\begin{array}{l}3,2 \\
9 \\
\end{array}$ & 17 \\
\hline $\begin{array}{l}\text { Cluster } \\
2\end{array}$ & 3 & $\begin{array}{l}1 \\
0\end{array}$ & & 1 & $\begin{array}{l}1 \\
3\end{array}$ & 0 & 8 & 0 & 0 & 5 & $\begin{array}{l}2,5 \\
1\end{array}$ & 13 \\
\hline $\begin{array}{l}\text { Cluster } \\
3\end{array}$ & 9 & $\begin{array}{l}1 \\
2\end{array}$ & 2 & 0 & $\begin{array}{l}2 \\
0\end{array}$ & 1 & 0 & $\begin{array}{l}2 \\
1\end{array}$ & 0 & 0 & $\begin{array}{l}2,5 \\
8\end{array}$ & 21 \\
\hline $\begin{array}{l}\text { Cluster } \\
4\end{array}$ & 5 & 7 & 0 & 12 & $\begin{array}{l}1 \\
2\end{array}$ & 0 & 4 & 8 & 0 & 0 & $\begin{array}{l}2,0 \\
6\end{array}$ & 12 \\
\hline 2009 & & & & & & & & & & & & 11 \\
\hline $\begin{array}{l}\text { Cluster } \\
1\end{array}$ & 3 & 0 & 3 & 0 & 2 & 1 & 1 & 0 & 0 & 2 & $\begin{array}{l}0,5 \\
7\end{array}$ & 3 \\
\hline $\begin{array}{l}\text { Cluster } \\
2\end{array}$ & 0 & 8 & 8 & 0 & 6 & 2 & 0 & 7 & 1 & 0 & $\begin{array}{l}1,9 \\
7\end{array}$ & 8 \\
\hline 2010 & & & & & & & & & & & & 55 \\
\hline $\begin{array}{l}\text { Cluster } \\
1\end{array}$ & 5 & 1 & 2 & 0 & $\begin{array}{l}2 \\
2 \\
\end{array}$ & 0 & 2 & 0 & $\begin{array}{l}1 \\
1\end{array}$ & 9 & $\begin{array}{l}3,2 \\
8\end{array}$ & 22 \\
\hline $\begin{array}{l}\text { Cluster } \\
2\end{array}$ & $\begin{array}{l}1 \\
0\end{array}$ & 4 & 0 & 14 & $\begin{array}{l}1 \\
2\end{array}$ & 2 & 5 & 8 & 1 & 0 & $\begin{array}{l}1.9 \\
0\end{array}$ & 14 \\
\hline $\begin{array}{l}\text { Cluster } \\
3\end{array}$ & 9 & 0 & 0 & 0 & $\begin{array}{l}1 \\
9\end{array}$ & 0 & 0 & $\begin{array}{l}1 \\
9\end{array}$ & 0 & 0 & $\begin{array}{l}2,8 \\
9\end{array}$ & 19 \\
\hline 2011 & & & & & & & & & & & & $\begin{array}{l}14 \\
4\end{array}$ \\
\hline $\begin{array}{l}\text { Cluster } \\
1\end{array}$ & $\begin{array}{l}1 \\
6 \\
\end{array}$ & 9 & 1 & 24 & $\begin{array}{l}2 \\
3 \\
\end{array}$ & 2 & 11 & 4 & 5 & 5 & $\begin{array}{l}1,2 \\
9\end{array}$ & 25 \\
\hline $\begin{array}{l}\text { Cluster } \\
2\end{array}$ & 1 & 4 & 4 & 0 & $\begin{array}{l}4 \\
2\end{array}$ & 5 & 23 & 1 & $\begin{array}{l}1 \\
8\end{array}$ & 5 & $\begin{array}{l}2,7 \\
7\end{array}$ & 47 \\
\hline $\begin{array}{l}\text { Cluster } \\
3\end{array}$ & $\begin{array}{l}3 \\
3 \\
\end{array}$ & 0 & $\begin{array}{l}3 \\
3\end{array}$ & 0 & $\begin{array}{l}3 \\
1\end{array}$ & 2 & 5 & $\begin{array}{l}1 \\
9\end{array}$ & 8 & 1 & $\begin{array}{l}2,9 \\
2\end{array}$ & 33 \\
\hline $\begin{array}{l}\text { Cluster } \\
4\end{array}$ & 0 & $\begin{array}{l}3 \\
9\end{array}$ & 9 & 0 & $\begin{array}{l}3 \\
9\end{array}$ & 0 & 0 & $\begin{array}{l}3 \\
9\end{array}$ & 0 & 0 & $\begin{array}{l}2,6 \\
7 \\
\end{array}$ & 39 \\
\hline 2012 & & & & & & & & & & & & $\begin{array}{l}12 \\
5 \\
\end{array}$ \\
\hline $\begin{array}{l}\text { Cluster } \\
1\end{array}$ & 9 & 1 & 2 & 17 & 8 & $\begin{array}{l}1 \\
1\end{array}$ & 9 & $\begin{array}{l}1 \\
0\end{array}$ & 0 & 0 & $\begin{array}{l}2,7 \\
7\end{array}$ & 19 \\
\hline $\begin{array}{l}\text { Cluster } \\
2\end{array}$ & 0 & 3 & 3 & 0 & $\begin{array}{l}3 \\
0\end{array}$ & 0 & 0 & $\begin{array}{l}3 \\
0\end{array}$ & 0 & 0 & $\begin{array}{l}2,9 \\
4\end{array}$ & 30 \\
\hline $\begin{array}{l}\text { Cluster } \\
3\end{array}$ & 0 & $\begin{array}{l}2 \\
1\end{array}$ & 2 & 0 & $\begin{array}{l}2 \\
1\end{array}$ & 0 & 0 & 0 & $\begin{array}{l}1 \\
3\end{array}$ & 8 & $\begin{array}{l}3,4 \\
0\end{array}$ & 21 \\
\hline $\begin{array}{l}\text { Cluster } \\
4\end{array}$ & 0 & $\begin{array}{l}2 \\
7\end{array}$ & 2 & 0 & $\begin{array}{l}2 \\
7\end{array}$ & 0 & 26 & 0 & 0 & 1 & $\begin{array}{l}2,3 \\
2\end{array}$ & 27 \\
\hline $\begin{array}{l}\text { Cluster } \\
5\end{array}$ & $\begin{array}{l}1 \\
2\end{array}$ & 0 & 8 & 4 & $\begin{array}{l}1 \\
2\end{array}$ & 0 & 10 & 0 & 0 & 2 & $\begin{array}{l}2,7 \\
1\end{array}$ & 12 \\
\hline $\begin{array}{l}\text { Cluster } \\
6\end{array}$ & $\begin{array}{l}1 \\
6\end{array}$ & 0 & $\begin{array}{l}1 \\
6\end{array}$ & 0 & $\begin{array}{l}1 \\
6\end{array}$ & 0 & 0 & 9 & 7 & 0 & $\begin{array}{l}3,4 \\
4\end{array}$ & 16 \\
\hline 2013 & & & & & & & & & & & & $\begin{array}{l}12 \\
5\end{array}$ \\
\hline $\begin{array}{l}\text { Cluster } \\
1\end{array}$ & 0 & $\begin{array}{l}4 \\
2 \\
\end{array}$ & 4 & 0 & $\begin{array}{l}4 \\
2 \\
\end{array}$ & 0 & 22 & 0 & $\begin{array}{l}1 \\
3 \\
\end{array}$ & 7 & $\begin{array}{l}2,6 \\
1\end{array}$ & 42 \\
\hline $\begin{array}{l}\text { Cluster } \\
2\end{array}$ & $\begin{array}{l}1 \\
8\end{array}$ & 4 & 0 & 22 & 9 & $\begin{array}{l}1 \\
3 \\
\end{array}$ & 18 & 0 & 3 & 1 & $\begin{array}{l}1,6 \\
2\end{array}$ & 22 \\
\hline $\begin{array}{l}\text { Cluster } \\
3\end{array}$ & $\begin{array}{l}2 \\
8\end{array}$ & 0 & 2 & 0 & $\begin{array}{l}2 \\
6\end{array}$ & 2 & 4 & $\begin{array}{l}1 \\
7\end{array}$ & 5 & 2 & $\begin{array}{l}2,9 \\
3\end{array}$ & 28 \\
\hline $\begin{array}{l}\text { Cluster } \\
4\end{array}$ & 0 & $\begin{array}{l}3 \\
3 \\
\end{array}$ & $\begin{array}{l}3 \\
2 \\
\end{array}$ & 1 & $\begin{array}{l}3 \\
3 \\
\end{array}$ & 0 & 0 & $\begin{array}{l}3 \\
3\end{array}$ & 0 & 0 & $\begin{array}{l}2,7 \\
7\end{array}$ & 33 \\
\hline 2014 & & & & & & & & & & & & 90 \\
\hline $\begin{array}{l}\text { Cluster } \\
1\end{array}$ & $\begin{array}{l}2 \\
2 \\
\end{array}$ & 0 & 8 & 4 & $\begin{array}{l}1 \\
9 \\
\end{array}$ & 3 & 4 & $\begin{array}{l}1 \\
4 \\
\end{array}$ & 2 & 2 & $\begin{array}{l}2,8 \\
2\end{array}$ & 22 \\
\hline $\begin{array}{l}\text { Cluster } \\
2\end{array}$ & $\begin{array}{l}2 \\
0\end{array}$ & 3 & 0 & 23 & $\begin{array}{l}1 \\
0\end{array}$ & $\begin{array}{l}1 \\
3 \\
\end{array}$ & 22 & 0 & 1 & 0 & $\begin{array}{l}1,5 \\
2\end{array}$ & 23 \\
\hline $\begin{array}{l}\text { Cluster } \\
3\end{array}$ & 0 & 1 & $\begin{array}{l}1 \\
4\end{array}$ & 0 & $\begin{array}{l}1 \\
0\end{array}$ & 4 & 14 & 0 & 0 & 0 & $\begin{array}{l}2,0 \\
6\end{array}$ & 14 \\
\hline
\end{tabular}

\begin{tabular}{|c|c|c|c|c|c|c|c|c|c|c|c|c|}
\hline \multirow{2}{*}{$\begin{array}{c}\text { Angka } \\
\text { tan }\end{array}$} & \multicolumn{2}{|c|}{$\mathbf{X}_{1}$} & \multicolumn{2}{|c|}{$\mathbf{X}_{2}$} & \multicolumn{2}{|c|}{$\mathbf{X}_{3}$} & \multicolumn{4}{|c|}{$\mathbf{X}_{4}$} & \multirow[t]{2}{*}{$\mathbf{X}_{5}$} & \multirow{2}{*}{$\begin{array}{l}X \\
6 \\
\end{array}$} \\
\hline & 1 & 2 & 1 & 2 & 1 & 2 & 1 & 2 & 3 & 4 & & \\
\hline $\begin{array}{l}\text { Cluster } \\
4\end{array}$ & 0 & $\begin{array}{l}3 \\
1 \\
\end{array}$ & 6 & 5 & $\begin{array}{l}3 \\
0 \\
\end{array}$ & 1 & 0 & $\begin{array}{l}1 \\
7 \\
\end{array}$ & $\begin{array}{l}1 \\
0\end{array}$ & 4 & $\begin{array}{l}3,0 \\
6\end{array}$ & 31 \\
\hline 2015 & & & & & & & & & & & & $\begin{array}{l}19 \\
3\end{array}$ \\
\hline $\begin{array}{l}\text { Cluster } \\
1\end{array}$ & $\begin{array}{l}2 \\
5\end{array}$ & $\begin{array}{l}6 \\
2\end{array}$ & $\begin{array}{l}1 \\
5\end{array}$ & 72 & $\begin{array}{l}8 \\
2\end{array}$ & 6 & 0 & $\begin{array}{l}5 \\
1\end{array}$ & $\begin{array}{l}2 \\
0\end{array}$ & $\begin{array}{l}1 \\
6\end{array}$ & $\begin{array}{l}3,2 \\
8\end{array}$ & 87 \\
\hline $\begin{array}{l}\text { Cluster } \\
2\end{array}$ & $\begin{array}{l}7 \\
2\end{array}$ & $\begin{array}{l}3 \\
4\end{array}$ & 0 & $\begin{array}{l}10 \\
6\end{array}$ & $\begin{array}{l}4 \\
1\end{array}$ & $\begin{array}{l}6 \\
5\end{array}$ & $\begin{array}{l}10 \\
6\end{array}$ & 0 & 0 & 0 & $\begin{array}{l}2,2 \\
1\end{array}$ & $\begin{array}{l}10 \\
6\end{array}$ \\
\hline 2016 & & & & & & & & & & & & 99 \\
\hline $\begin{array}{l}\text { Cluster } \\
1\end{array}$ & 0 & $\begin{array}{l}2 \\
3 \\
\end{array}$ & $\begin{array}{l}2 \\
3\end{array}$ & 0 & $\begin{array}{l}2 \\
3 \\
\end{array}$ & 0 & 13 & 0 & 0 & $\begin{array}{l}1 \\
0\end{array}$ & $\begin{array}{l}2,7 \\
5\end{array}$ & 23 \\
\hline $\begin{array}{l}\text { Cluster } \\
2\end{array}$ & 8 & $\begin{array}{l}1 \\
2\end{array}$ & $\begin{array}{l}2 \\
0\end{array}$ & 0 & $\begin{array}{l}2 \\
0\end{array}$ & 0 & 0 & $\begin{array}{l}2 \\
0\end{array}$ & 0 & 0 & $\begin{array}{l}3,0 \\
8\end{array}$ & 20 \\
\hline $\begin{array}{l}\text { Cluster } \\
3 \\
\end{array}$ & 0 & $\begin{array}{l}2 \\
8 \\
\end{array}$ & 2 & 26 & $\begin{array}{l}1 \\
4 \\
\end{array}$ & $\begin{array}{l}1 \\
4 \\
\end{array}$ & 12 & 9 & 4 & 3 & $\begin{array}{l}2,2 \\
2 \\
\end{array}$ & 28 \\
\hline $\begin{array}{l}\text { Cluster } \\
4 \\
\end{array}$ & $\begin{array}{l}2 \\
5 \\
\end{array}$ & 3 & $\begin{array}{l}1 \\
5\end{array}$ & 13 & $\begin{array}{l}2 \\
6 \\
\end{array}$ & 2 & 13 & 5 & $\begin{array}{l}1 \\
0 \\
\end{array}$ & 0 & $\begin{array}{l}2,3 \\
9 \\
\end{array}$ & 28 \\
\hline 2017 & & & & & & & & & & & & $\begin{array}{l}10 \\
2\end{array}$ \\
\hline $\begin{array}{l}\text { Cluster } \\
1\end{array}$ & $\begin{array}{l}3 \\
5 \\
\end{array}$ & $\begin{array}{l}2 \\
3 \\
\end{array}$ & $\begin{array}{l}2 \\
0\end{array}$ & 38 & $\begin{array}{l}4 \\
3 \\
\end{array}$ & $\begin{array}{l}1 \\
5\end{array}$ & 31 & $\begin{array}{l}1 \\
7\end{array}$ & 6 & 4 & $\begin{array}{l}2,8 \\
2\end{array}$ & 58 \\
\hline $\begin{array}{l}\text { Cluster } \\
2\end{array}$ & 0 & $\begin{array}{l}4 \\
4 \\
\end{array}$ & $\begin{array}{l}4 \\
4\end{array}$ & 0 & $\begin{array}{l}4 \\
4 \\
\end{array}$ & 0 & 7 & $\begin{array}{l}1 \\
7 \\
\end{array}$ & $\begin{array}{l}1 \\
2 \\
\end{array}$ & 8 & $\begin{array}{l}2,8 \\
6 \\
\end{array}$ & 44 \\
\hline 2018 & & & & & & & & & & & & $\begin{array}{l}10 \\
9\end{array}$ \\
\hline $\begin{array}{l}\text { Cluster } \\
1 \\
\end{array}$ & $\begin{array}{l}5 \\
1 \\
\end{array}$ & 0 & $\begin{array}{l}2 \\
5 \\
\end{array}$ & 26 & $\begin{array}{l}3 \\
9 \\
\end{array}$ & $\begin{array}{l}1 \\
2 \\
\end{array}$ & 17 & $\begin{array}{l}2 \\
2 \\
\end{array}$ & 8 & 4 & $\begin{array}{l}2,7 \\
4\end{array}$ & 51 \\
\hline $\begin{array}{l}\text { Cluster } \\
2\end{array}$ & 0 & $\begin{array}{l}5 \\
8 \\
\end{array}$ & $\begin{array}{l}3 \\
7\end{array}$ & 21 & $\begin{array}{l}5 \\
0 \\
\end{array}$ & 8 & 16 & $\begin{array}{l}1 \\
5\end{array}$ & $\begin{array}{l}1 \\
6\end{array}$ & $\begin{array}{l}1 \\
1\end{array}$ & $\begin{array}{l}2,8 \\
0 \\
\end{array}$ & 58 \\
\hline 2019 & & & & & & & & & & & & 92 \\
\hline $\begin{array}{l}\text { Cluster } \\
1\end{array}$ & $\begin{array}{l}3 \\
5\end{array}$ & $\begin{array}{l}1 \\
1\end{array}$ & $\begin{array}{l}1 \\
6\end{array}$ & 30 & $\begin{array}{l}4 \\
3\end{array}$ & 3 & 20 & $\begin{array}{l}1 \\
2\end{array}$ & $\begin{array}{l}1 \\
2\end{array}$ & 2 & $\begin{array}{l}2,6 \\
4\end{array}$ & 46 \\
\hline $\begin{array}{l}\text { Cluster } \\
2\end{array}$ & 0 & $\begin{array}{l}4 \\
6\end{array}$ & $\begin{array}{l}4 \\
6\end{array}$ & 0 & $\begin{array}{l}3 \\
5\end{array}$ & $\begin{array}{l}1 \\
1\end{array}$ & 14 & $\begin{array}{l}1 \\
9\end{array}$ & 9 & 4 & $\begin{array}{l}3,1 \\
3\end{array}$ & 46 \\
\hline
\end{tabular}

TABEL VI

INFORMASI KLASTER MAHASISWA NON JALUR PRESTASI (NJP) ANGKATAN 2008 SD 2019 DENGAN VARIABEL $\mathrm{X}_{1}$ SD X $_{6}$

\begin{tabular}{|c|c|c|c|c|c|c|c|c|c|c|c|c|}
\hline \multirow{2}{*}{$\begin{array}{c}\text { Angka } \\
\text { tan }\end{array}$} & \multicolumn{2}{|c|}{$\mathbf{X}_{1}$} & \multicolumn{2}{|c|}{$\mathbf{X}_{2}$} & \multicolumn{2}{|c|}{$\mathbf{X}_{3}$} & \multicolumn{4}{|c|}{$\mathbf{X}_{4}$} & \multirow[t]{2}{*}{$\mathrm{X}_{5}$} & \multirow{2}{*}{$\begin{array}{l}X \\
6 \\
\end{array}$} \\
\hline & 1 & 2 & 1 & 2 & 1 & 2 & 1 & 2 & 3 & 4 & & \\
\hline 2008 & & & & & & & & & & & & $\begin{array}{l}30 \\
5\end{array}$ \\
\hline $\begin{array}{l}\text { Cluster } \\
1\end{array}$ & 0 & $\begin{array}{l}6 \\
5 \\
\end{array}$ & 65 & 0 & 65 & 0 & 0 & $\begin{array}{l}6 \\
5 \\
\end{array}$ & 0 & 0 & $\begin{array}{l}2,3 \\
9\end{array}$ & 65 \\
\hline $\begin{array}{l}\text { Cluster } \\
2\end{array}$ & $\begin{array}{l}1 \\
5\end{array}$ & $\begin{array}{l}2 \\
9\end{array}$ & 43 & 1 & 44 & 0 & 0 & 0 & $\begin{array}{l}3 \\
5\end{array}$ & 9 & $\begin{array}{l}3,0 \\
1\end{array}$ & 44 \\
\hline $\begin{array}{l}\text { Cluster } \\
3\end{array}$ & $\begin{array}{l}1 \\
7\end{array}$ & $\begin{array}{l}1 \\
1\end{array}$ & 18 & $\begin{array}{l}1 \\
0\end{array}$ & 0 & $\begin{array}{l}2 \\
8 \\
\end{array}$ & $\begin{array}{l}1 \\
5\end{array}$ & $\begin{array}{l}1 \\
0\end{array}$ & 3 & 0 & $\begin{array}{l}2,5 \\
1\end{array}$ & 28 \\
\hline $\begin{array}{l}\text { Cluster } \\
4\end{array}$ & $\begin{array}{l}2 \\
2 \\
\end{array}$ & $\begin{array}{l}1 \\
8 \\
\end{array}$ & 0 & $\begin{array}{l}4 \\
0\end{array}$ & 40 & 0 & $\begin{array}{l}4 \\
0 \\
\end{array}$ & 0 & 0 & 0 & $\begin{array}{l}1,9 \\
9\end{array}$ & 40 \\
\hline $\begin{array}{l}\text { Cluster } \\
5 \\
\end{array}$ & 0 & $\begin{array}{l}3 \\
4 \\
\end{array}$ & 34 & 0 & 34 & 0 & $\begin{array}{l}3 \\
4 \\
\end{array}$ & 0 & 0 & 0 & $\begin{array}{l}2,0 \\
8 \\
\end{array}$ & 34 \\
\hline $\begin{array}{l}\text { Cluster } \\
6\end{array}$ & $\begin{array}{l}5 \\
4 \\
\end{array}$ & 0 & 54 & 0 & 54 & 0 & $\begin{array}{l}2 \\
0\end{array}$ & $\begin{array}{l}3 \\
4 \\
\end{array}$ & 0 & 0 & $\begin{array}{l}2,4 \\
4\end{array}$ & 54 \\
\hline $\begin{array}{l}\text { Cluster } \\
7\end{array}$ & $\begin{array}{l}1 \\
9\end{array}$ & $\begin{array}{l}2 \\
1\end{array}$ & 0 & $\begin{array}{l}4 \\
0\end{array}$ & 40 & 0 & 0 & $\begin{array}{l}3 \\
5\end{array}$ & 4 & 1 & $\begin{array}{l}2,4 \\
0\end{array}$ & 40 \\
\hline 2009 & & & & & & & & & & & & $\begin{array}{l}24 \\
9\end{array}$ \\
\hline $\begin{array}{l}\text { Cluster } \\
1\end{array}$ & $\begin{array}{l}5 \\
6\end{array}$ & $\begin{array}{l}8 \\
4 \\
\end{array}$ & $\begin{array}{l}14 \\
0\end{array}$ & 0 & $\begin{array}{l}14 \\
0\end{array}$ & 0 & 2 & $\begin{array}{l}9 \\
1\end{array}$ & $\begin{array}{l}3 \\
3\end{array}$ & $\begin{array}{l}1 \\
4\end{array}$ & $\begin{array}{l}2,8 \\
1\end{array}$ & $\begin{array}{l}14 \\
0\end{array}$ \\
\hline $\begin{array}{l}\text { Cluster } \\
2\end{array}$ & $\begin{array}{l}6 \\
3\end{array}$ & $\begin{array}{l}4 \\
6\end{array}$ & 36 & $\begin{array}{l}7 \\
3\end{array}$ & 95 & $\begin{array}{l}1 \\
4\end{array}$ & $\begin{array}{l}6 \\
7\end{array}$ & $\begin{array}{l}3 \\
1\end{array}$ & $\begin{array}{l}1 \\
0\end{array}$ & 1 & $\begin{array}{l}2,0 \\
4\end{array}$ & $\begin{array}{l}10 \\
9\end{array}$ \\
\hline
\end{tabular}




\begin{tabular}{|c|c|c|c|c|c|c|c|c|c|c|c|c|}
\hline \multirow{2}{*}{$\begin{array}{c}\text { Angka } \\
\text { tan }\end{array}$} & \multicolumn{2}{|c|}{$\mathbf{X}_{1}$} & \multicolumn{2}{|c|}{$\mathbf{X}_{2}$} & \multicolumn{2}{|c|}{$\mathbf{X}_{3}$} & \multicolumn{4}{|c|}{$\mathbf{X}_{4}$} & \multirow[t]{2}{*}{$\mathbf{X}_{5}$} & \multirow{2}{*}{$\begin{array}{c}X \\
6 \\
\end{array}$} \\
\hline & 1 & 2 & 1 & 2 & 1 & 2 & 1 & 2 & 3 & 4 & & \\
\hline 2010 & & & & & & & & & & & & $\begin{array}{l}20 \\
9\end{array}$ \\
\hline $\begin{array}{l}\text { Cluster } \\
1\end{array}$ & 0 & $\begin{array}{l}7 \\
3 \\
\end{array}$ & 73 & 0 & 73 & 0 & $\begin{array}{l}2 \\
9 \\
\end{array}$ & $\begin{array}{l}4 \\
3 \\
\end{array}$ & 0 & 1 & $\begin{array}{l}2,2 \\
3\end{array}$ & 73 \\
\hline $\begin{array}{l}\text { Cluster } \\
2\end{array}$ & $\begin{array}{l}4 \\
4\end{array}$ & $\begin{array}{l}2 \\
8\end{array}$ & 14 & $\begin{array}{l}5 \\
8\end{array}$ & 51 & $\begin{array}{l}2 \\
1\end{array}$ & $\begin{array}{l}4 \\
9\end{array}$ & $\begin{array}{l}2 \\
3\end{array}$ & 0 & 0 & $\begin{array}{l}2,1 \\
1\end{array}$ & 72 \\
\hline $\begin{array}{l}\text { Cluster } \\
3\end{array}$ & $\begin{array}{l}3 \\
0\end{array}$ & $\begin{array}{l}3 \\
4 \\
\end{array}$ & 57 & 7 & 64 & 0 & 0 & $\begin{array}{l}1 \\
9 \\
\end{array}$ & $\begin{array}{l}3 \\
1\end{array}$ & $\begin{array}{l}1 \\
4 \\
\end{array}$ & $\begin{array}{l}2,5 \\
3 \\
\end{array}$ & 64 \\
\hline 2011 & & & & & & & & & & & & $\begin{array}{l}10 \\
7\end{array}$ \\
\hline $\begin{array}{l}\text { Cluster } \\
1 \\
\end{array}$ & $\begin{array}{l}3 \\
5 \\
\end{array}$ & $\begin{array}{l}2 \\
6 \\
\end{array}$ & 7 & $\begin{array}{l}5 \\
4 \\
\end{array}$ & 50 & $\begin{array}{l}1 \\
1 \\
\end{array}$ & $\begin{array}{l}4 \\
1 \\
\end{array}$ & $\begin{array}{l}1 \\
7 \\
\end{array}$ & 2 & 1 & $\begin{array}{l}1,7 \\
2\end{array}$ & 61 \\
\hline $\begin{array}{l}\text { Cluster } \\
2 \\
\end{array}$ & $\begin{array}{l}2 \\
1 \\
\end{array}$ & $\begin{array}{l}2 \\
5 \\
\end{array}$ & 46 & 0 & 42 & 4 & 5 & $\begin{array}{l}2 \\
5 \\
\end{array}$ & 8 & 8 & $\begin{array}{l}2,1 \\
2 \\
\end{array}$ & 46 \\
\hline 2012 & & & & & & & & & & & & $\begin{array}{l}11 \\
9 \\
\end{array}$ \\
\hline $\begin{array}{l}\text { Cluster } \\
1\end{array}$ & $\begin{array}{l}2 \\
8 \\
\end{array}$ & $\begin{array}{l}4 \\
0\end{array}$ & 59 & 9 & 61 & 7 & $\begin{array}{l}1 \\
5\end{array}$ & $\begin{array}{l}2 \\
9 \\
\end{array}$ & $\begin{array}{l}1 \\
9 \\
\end{array}$ & 5 & $\begin{array}{l}2,8 \\
1 \\
\end{array}$ & 68 \\
\hline $\begin{array}{l}\text { Cluster } \\
2\end{array}$ & $\begin{array}{l}3 \\
2 \\
\end{array}$ & $\begin{array}{l}1 \\
9 \\
\end{array}$ & 0 & $\begin{array}{l}5 \\
1 \\
\end{array}$ & 39 & $\begin{array}{l}1 \\
2 \\
\end{array}$ & $\begin{array}{l}3 \\
6 \\
\end{array}$ & $\begin{array}{l}1 \\
4 \\
\end{array}$ & 1 & 0 & $\begin{array}{l}1,8 \\
6 \\
\end{array}$ & 51 \\
\hline 2013 & & & & & & & & & & & & 80 \\
\hline $\begin{array}{l}\text { Cluster } \\
1\end{array}$ & $\begin{array}{l}2 \\
8 \\
\end{array}$ & 4 & 0 & 3 & 30 & 2 & $\begin{array}{l}1 \\
7\end{array}$ & $\begin{array}{l}1 \\
1\end{array}$ & 2 & 2 & $\begin{array}{l}2,2 \\
2\end{array}$ & 32 \\
\hline $\begin{array}{l}\text { Cluster } \\
2\end{array}$ & 2 & $\begin{array}{l}2 \\
1\end{array}$ & 13 & $\begin{array}{l}1 \\
0\end{array}$ & 17 & 6 & $\begin{array}{l}2 \\
1 \\
\end{array}$ & 0 & 2 & 0 & $\begin{array}{l}2,2 \\
8 \\
\end{array}$ & 23 \\
\hline $\begin{array}{l}\text { Cluster } \\
3 \\
\end{array}$ & $\begin{array}{l}1 \\
2 \\
\end{array}$ & $\begin{array}{l}1 \\
3 \\
\end{array}$ & 25 & 0 & 25 & 0 & 6 & $\begin{array}{l}1 \\
4 \\
\end{array}$ & 2 & 3 & $\begin{array}{l}2,5 \\
8 \\
\end{array}$ & 25 \\
\hline 2014 & & & & & & & & & & & & 81 \\
\hline $\begin{array}{l}\text { Cluster } \\
1\end{array}$ & $\begin{array}{l}1 \\
1 \\
\end{array}$ & $\begin{array}{l}3 \\
4 \\
\end{array}$ & 45 & 0 & 39 & 6 & $\begin{array}{l}1 \\
6 \\
\end{array}$ & $\begin{array}{l}1 \\
5\end{array}$ & $\begin{array}{l}1 \\
1 \\
\end{array}$ & 3 & $\begin{array}{l}2,1 \\
9 \\
\end{array}$ & 45 \\
\hline $\begin{array}{l}\text { Cluster } \\
2\end{array}$ & $\begin{array}{l}3 \\
0 \\
\end{array}$ & 6 & 0 & $\begin{array}{l}3 \\
6 \\
\end{array}$ & 28 & 8 & $\begin{array}{l}2 \\
4 \\
\end{array}$ & $\begin{array}{l}1 \\
0\end{array}$ & 1 & 1 & $\begin{array}{l}2,0 \\
6 \\
\end{array}$ & 36 \\
\hline 2015 & & & & & & & & & & & & 61 \\
\hline $\begin{array}{l}\text { Cluster } \\
1\end{array}$ & 7 & 6 & 0 & 1 & 12 & 1 & 0 & 9 & 2 & 2 & $\begin{array}{l}2,8 \\
6 \\
\end{array}$ & 13 \\
\hline $\begin{array}{l}\text { Cluster } \\
2\end{array}$ & $\begin{array}{l}1 \\
5 \\
\end{array}$ & $\begin{array}{l}1 \\
6 \\
\end{array}$ & 0 & $\begin{array}{l}3 \\
1 \\
\end{array}$ & 31 & 0 & $\begin{array}{l}2 \\
8 \\
\end{array}$ & 0 & 3 & 0 & $\begin{array}{l}2,2 \\
5 \\
\end{array}$ & 31 \\
\hline $\begin{array}{l}\text { Cluster } \\
3 \\
\end{array}$ & 9 & 8 & 0 & $\begin{array}{l}1 \\
7 \\
\end{array}$ & 0 & $\begin{array}{l}1 \\
7 \\
\end{array}$ & $\begin{array}{l}1 \\
5 \\
\end{array}$ & 2 & 0 & 0 & $\begin{array}{l}1,9 \\
0 \\
\end{array}$ & 17 \\
\hline 2016 & & & & & & & & & & & & $\begin{array}{l}11 \\
1\end{array}$ \\
\hline $\begin{array}{l}\text { Cluster } \\
1\end{array}$ & $\begin{array}{l}2 \\
9\end{array}$ & 3 & 12 & $\begin{array}{l}4 \\
9\end{array}$ & 42 & $\begin{array}{l}1 \\
9\end{array}$ & $\begin{array}{l}6 \\
0\end{array}$ & 1 & 0 & 0 & $\begin{array}{l}2,1 \\
2\end{array}$ & 61 \\
\hline $\begin{array}{l}\text { Cluster } \\
2\end{array}$ & $\begin{array}{l}2 \\
5 \\
\end{array}$ & $\begin{array}{l}2 \\
5\end{array}$ & 23 & $\begin{array}{l}2 \\
7\end{array}$ & 45 & 5 & 0 & $\begin{array}{l}3 \\
9 \\
\end{array}$ & 8 & 3 & $\begin{array}{l}2,5 \\
1 \\
\end{array}$ & 50 \\
\hline 2017 & & & & & & & & & & & & 99 \\
\hline $\begin{array}{l}\text { Cluster } \\
1\end{array}$ & $\begin{array}{l}2 \\
4 \\
\end{array}$ & 3 & 12 & $\begin{array}{l}4 \\
9 \\
\end{array}$ & 42 & $\begin{array}{l}1 \\
9 \\
\end{array}$ & $\begin{array}{l}6 \\
0 \\
\end{array}$ & 1 & 0 & 0 & $\begin{array}{l}2,1 \\
2 \\
\end{array}$ & 61 \\
\hline $\begin{array}{l}\text { Cluster } \\
2\end{array}$ & 4 & $\begin{array}{l}2 \\
7 \\
\end{array}$ & 0 & 3 & 21 & $\begin{array}{l}1 \\
0\end{array}$ & $\begin{array}{l}2 \\
3 \\
\end{array}$ & 6 & 2 & 0 & $\begin{array}{l}2,3 \\
5\end{array}$ & 31 \\
\hline $\begin{array}{l}\text { Cluster } \\
3 \\
\end{array}$ & $\begin{array}{l}3 \\
5 \\
\end{array}$ & 0 & 0 & $\begin{array}{l}3 \\
5 \\
\end{array}$ & 35 & 0 & \begin{tabular}{|l}
3 \\
5 \\
\end{tabular} & 0 & 0 & 0 & $\begin{array}{l}2,2 \\
9 \\
\end{array}$ & 35 \\
\hline 2018 & & & & & & & & & & & & $\begin{array}{l}13 \\
5 \\
\end{array}$ \\
\hline $\begin{array}{l}\text { Cluster } \\
1\end{array}$ & $\begin{array}{l}2 \\
6 \\
\end{array}$ & 3 & 48 & $\begin{array}{l}1 \\
2\end{array}$ & 46 & $\begin{array}{l}1 \\
4 \\
\end{array}$ & $\begin{array}{l}1 \\
7 \\
\end{array}$ & $\begin{array}{l}2 \\
9 \\
\end{array}$ & $\begin{array}{l}1 \\
0\end{array}$ & 4 & $\begin{array}{l}2,6 \\
7\end{array}$ & 60 \\
\hline $\begin{array}{l}\text { Cluster } \\
2\end{array}$ & 4 & $\begin{array}{l}2 \\
9 \\
\end{array}$ & 0 & $\begin{array}{l}7 \\
5 \\
\end{array}$ & 57 & $\begin{array}{l}1 \\
8 \\
\end{array}$ & $\begin{array}{l}5 \\
9 \\
\end{array}$ & $\begin{array}{l}1 \\
0\end{array}$ & 4 & 2 & $\begin{array}{l}2,4 \\
6 \\
\end{array}$ & 75 \\
\hline 2019 & & & & & & & & & & & & $\begin{array}{l}11 \\
8\end{array}$ \\
\hline $\begin{array}{l}\text { Cluster } \\
1\end{array}$ & $\begin{array}{l}1 \\
8 \\
\end{array}$ & $\begin{array}{l}3 \\
2 \\
\end{array}$ & 44 & 6 & 43 & 7 & $\begin{array}{l}2 \\
4 \\
\end{array}$ & 9 & $\begin{array}{l}1 \\
1\end{array}$ & 6 & $\begin{array}{l}2,8 \\
2\end{array}$ & 50 \\
\hline $\begin{array}{l}\text { Cluster } \\
2\end{array}$ & $\begin{array}{l}5 \\
1\end{array}$ & $\begin{array}{l}1 \\
7\end{array}$ & 0 & $\begin{array}{l}6 \\
8\end{array}$ & 58 & $\begin{array}{l}1 \\
0\end{array}$ & $\begin{array}{l}4 \\
1\end{array}$ & $\begin{array}{l}2 \\
5\end{array}$ & 2 & 0 & $\begin{array}{l}2,5 \\
6\end{array}$ & 68 \\
\hline
\end{tabular}

TABEL VII

INFORMASI KLASTER MAHASISWA NON JALUR PRESTASI (NJP) ANGKATAN 2008 SD 2019 DENGAN VARIABEL $\mathrm{X}_{7}$ SD X $_{10}$ [ LANJUTAN VARIABEL DARI TABEL 6]

\begin{tabular}{|c|c|c|c|c|c|}
\hline Angkatan & $X_{7}$ & $\mathbf{X}_{8}$ & $X_{9}$ & $X_{10}$ & Total \\
\hline 2008 & & & & & 305 \\
\hline Cluster 1 & 129,08 & 126,46 & 132,77 & 106,31 & \\
\hline Cluster 2 & 144,09 & 153,86 & 144,32 & 127,05 & \\
\hline Cluster 3 & 117,14 & 118,21 & 136,43 & 88,93 & \\
\hline Cluster 4 & 136,75 & 107,75 & 116,00 & 109,50 & \\
\hline Cluster 5 & 127,35 & 117,94 & 122,65 & 95,29 & \\
\hline Cluster 6 & 148,52 & 143,89 & 145,93 & 125,93 & \\
\hline Cluster 7 & 175,25 & 149,50 & 140,00 & 144,25 & \\
\hline 2009 & & & & & 249 \\
\hline Cluster 1 & 147,64 & 142,36 & 139,00 & 133,57 & \\
\hline Cluster 2 & 116,15 & 105,60 & 112,20 & 103,85 & \\
\hline 2010 & & & & & 209 \\
\hline Cluster 1 & 121,92 & 89,32 & 96,99 & 97,67 & \\
\hline Cluster 2 & 93,47 & 85,42 & 93,89 & 89,31 & \\
\hline Cluster 3 & 152,50 & 136,72 & 124,06 & 135,00 & \\
\hline 2011 & & & & & 107 \\
\hline Cluster 1 & 77,38 & 66,23 & 78,85 & 79,34 & \\
\hline Cluster 2 & 136,74 & 119,78 & 116,96 & 118,91 & \\
\hline 2012 & & & & & 119 \\
\hline Cluster 1 & 121,62 & 106,32 & 106,03 & 109,71 & \\
\hline Cluster 2 & 60,00 & 60,00 & 58,04 & 66,47 & \\
\hline 2013 & & & & & 80 \\
\hline Cluster 1 & 59,38 & 73,44 & 67,81 & 79,38 & \\
\hline Cluster 2 & 65,22 & 67,83 & 73,91 & 76,09 & \\
\hline Cluster 3 & 120,00 & 121,60 & 112,00 & 101,20 & \\
\hline 2014 & & & & & 81 \\
\hline Cluster 1 & 113,11 & 79,11 & 102,67 & 102,22 & \\
\hline Cluster 2 & 65,83 & 66,94 & 82,22 & 58,61 & \\
\hline 2015 & & & & & 61 \\
\hline Cluster 1 & 96,92 & 100,7 & 100,00 & 100,00 & \\
\hline Cluster 2 & 48,06 & 56,77 & 56,45 & 50,97 & \\
\hline Cluster 3 & 35,29 & 32,35 & 57,06 & 57,06 & \\
\hline 2016 & & & & & 111 \\
\hline Cluster 1 & 41,80 & 29,67 & 61,64 & 53,28 & \\
\hline Cluster 2 & 98,80 & 91,20 & 92,60 & 94,60 & \\
\hline 2017 & & & & & 99 \\
\hline Cluster 1 & 102,12 & 82,12 & 90,00 & 96,36 & \\
\hline Cluster 2 & 47,10 & 63,87 & 70,65 & 56,77 & \\
\hline Cluster 3 & 49,14 & 52,29 & 63,43 & 64,00 & \\
\hline 2018 & & & & & 135 \\
\hline Cluster 1 & 98,17 & 96,33 & 98,50 & 106,17 & \\
\hline Cluster 2 & 68,00 & 41,07 & 69,87 & 70,53 & \\
\hline 2019 & & & & & 118 \\
\hline Cluster 1 & 108,00 & 94,80 & 91,00 & 78,20 & \\
\hline Cluster 2 & 61,03 & 59,12 & 70,44 & 62,06 & \\
\hline
\end{tabular}


TABEL VIII

RATA-RATA NILAI NUMERIK, VERBAL , SPATIAL DAN ANALOGI PADA MAHASIWA NON JALUR PRESTASI (NJP) ANGKATAN 2008 SD 2019

\begin{tabular}{|c|c|c|c|c|c|c|}
\hline \multirow{2}{*}{$\begin{array}{c}\text { Angk } \\
\text { atan }\end{array}$} & \multicolumn{5}{|c|}{ Rata-rata } & \multirow{2}{*}{$\begin{array}{c}\Sigma \\
\text { Data }\end{array}$} \\
\hline & Num & Verb & Spat & Analiti & IPS1 & \\
\hline 2008 & 140,46 & 132,36 & 134,72 & 115,34 & 2,4114 & 305 \\
\hline 2009 & 133,86 & 126,27 & 127,27 & 120,56 & 2,4789 & 249 \\
\hline 2010 & 121,48 & 102,49 & 104,21 & 106,22 & 2,2799 & 209 \\
\hline 2011 & 102.90 & 89,25 & 95,23 & 96,36 & 1,8936 & 107 \\
\hline 2012 & 95,21 & 86,64 & 85,46 & 91,18 & 2,4044 & 119 \\
\hline 2013 & 80,00 & 86,88 & 83,37 & 85,25 & 2,3512 & 80 \\
\hline 2014 & 92,10 & 73,70 & 93,58 & 82,84 & 2,1332 & 81 \\
\hline 2015 & 54,92 & 59,34 & 65,90 & 63,11 & 2,2863 & 61 \\
\hline 2016 & 67,48 & 57,39 & 75,59 & 71,89 & 2,2969 & 111 \\
\hline 2017 & 66,16 & 65,86 & 74,55 & 72,53 & 2,3938 & 99 \\
\hline 2018 & 81,41 & 65,63 & 82,59 & 86,37 & 2,5510 & 135 \\
\hline 2019 & 80,93 & 74,24 & 79,15 & 68,90 & 2,6735 & 118 \\
\hline
\end{tabular}

\section{B. Pembahasan}

Dari Tabel 5 yang disajikan dari hasil metode TwoStep Clustering dapat dilihat pada karakteristik klaster-klaster yang muncul pada tiap angkatan untuk mahasiswa JP . Berikut ini ciri-ciri klaster yang muncul pada dataset mahasiswa Jalur Prestasi:

- Untuk angkatan 2008 yang melalui JP, ciri- ciri centroid klaster: angkatan 2008 menjadi 4 klaster. Klaster 1 mempunyai karakteristik mahasiswa dengan rata-rata IPS 1 yang tertinggi dan mempunyali level bahasa Inggris = 3. Sedangkan klaster 4 mempunyai karakteristik IPS 1 terendah dia antara 4 klaster dan kebanyakan lokasi SMA nya di luar Jawa. Selain itu klaster 4 mempunyai level bahasa Inggris di level 1 dan level 2.

- Untuk angkatan 2009 yang melalui JP, ciri- ciri centroid klaster: angkatan 2009 menjadi 2 klaster. Klaster 1 mempunyai rata-rata IPS 1 yang rendah dan status SMA adalah Negeri, sedangkan klaster 2 mempunyai rata-rata IPS1 yang tinggi dan status SMA adalah Swasta.

- Untuk angkatan 2010 yang melalui JP, ciri- ciri centroid klaster : angkatan 2010 menjadi 3 klaster. Klaster 1 mempunyai rata-rata IPS 1 tertinggi, klaster 2 mempunyai rata-rata IPS1 terendah dari antar 3 kelompok tersebut, sedangkan klaster 3 mempunyai rata-rata IPS1 yang sedang . Karakteristik klaster 1 yang lain adalah mempunyai level bahasa Inggris yang tinggi dibandingkan klaster 2 dan klaster 3. Dan klaster 2 mempunyai karakteristik lokasi SMA berasal dari luar Jawa, sedangkan klaster 1 dan klaster 3 lokasi SMA bersalal dari Jawa.

- Untuk angkatan 2011 yang melalui JP, ciri- ciri centroid klaster: angkatan 2011 menjadi 4 klaster . Klaster 1 mempunyai IPS1 yang terendah daripada IPS1 klaster yang lain. Selain itu klaster 1 mempunyai karakteristik yang berbeda dengan 3 klaster yang lain yaitu lokasi SMA sebagian besar berasal dari luar Jawa. Sedangkan klaster 3 mempunyai rata-rata IPS 1 yang tertinggi, karakteristik yang lain adalah pada status SMA pada klaster 1 adalah merupakan SMA Negeri.

- Untuk angkatan 2012 yang melalui JP, ciri- ciri centroid klaster: angkatan 2012 menjadi 6 klaster. Klaster 4 mepunyai rata-rata IPS 1 yang terendah dan klaster 3 mempunyaia rata-rata IPS 1 tertinggi. Klaster 4 mempunyai karakteristik status SMA sebagai SMA Swasta sedangkan klaster 6 dengan status SMA Nageri. Selain itu klaster 4 mempunyai level bahasa Inggris level 1 sedangkan klaster 6 mempunyai level bahasa Inggris di level 2 dan level 3. Klaster 2 mempunyai karakteristik lokasi SMA sebagai SMA dari luar Jawa sedangkan klaster 3 dengan sebagian besar lokasi SMA di Jawa.

- Untuk angkatan 2013 yang melalui JP, ciri- ciri centroid klaster: angkatan 2013 menjadi 4 klaster. Klaster 2 mepunyai rata-rata IPS 1 yang terendah dan klaster 3 mempunyaia rata-rata IPS 1 tertinggi. Dan klaster 2 mempunyai level bahasa Inggris level 1 sedangkan klaster 3 mempunyai level bahasa Inggris di level 2 dan level 3.

- Untuk angkatan 2014 yang melalui JP, ciri- ciri centroid klaster: angkatan 2014 menjadi 4 klaster. Klaster 2 mepunyai rata-rata IPS 1 yang terendah dan klaster 4 mempunyaia rata-rata IPS 1 tertinggi. Demikian pula klaster 2 mempunyai level bahasa Inggris level 1 sedangkan klaster 4 mempunyai level bahasa Inggris sebagian besar di level 2 dan level 3.

- Untuk angkatan 2015 yang melalui JP, ciri- ciri centroid klaster: angkatan 2015 menjadi 2 klaster. Klaster 2 mepunyai rata-rata IPS 1 yang rendah dan klaster 1 mempunyaia rata-rata IPS 1 tinggi. Demikian pula klaster 2 mempunyai level bahasa Inggris level 1 sedangkan klaster 1 mempunyai level bahasa Inggris sebagian besar di level 2, 3 dan 4. Kecenderungan klaster dengan IPS1 tinggi adalah Status SMA Swasta dan kategori SMA adalah SMA umum.

- Untuk angkatan 2016 yang melalui JP, ciri- ciri centroid klaster: angkatan 2016 menjadi 4 klaster. Klaster 3 mepunyai rata-rata IPS 1 yang terendah dan klaster 2 mempunyaia rata-rata IPS 1 tertinggi. Demikian pula klaster 3 mempunyai level bahasa Inggris kebanyakan di level 1 dan 2 , sedangkan klaster 2 mempunyai level bahasa Inggris di level 2. Selain itu klaster 2 kecenderungan lokasi SMA nya di Jawa dan klaster 3 kecenderungan lokasi SMA nya di luar Jawa.

- Untuk angkatan 2017 yang melalui JP, ciri- ciri centroid klaster: angkatan 2017 menjadi 2 klaster. Dan dua klaster tersebut mempunyai rata-rata IPS1 yang tidak berbeda jauh yaitu klaster 1 dengan rata-rata IPS1 sebesar 2,82 sedang klaster 2 sebesar 2,86.

- Untuk angkatan 2018 yang melalui JP, ciri- ciri centroid klaster: angkatan 2018 menjadi 2 klaster. Dan dua klaster tersebut mempunyai rata-rata IPS1 yang tidak berbeda jauh yaitu klaster 1 dengan rata-rata IPS1 sebesar 2,74 sedang klaster 2 sebesar 2,80.

- Untuk angkatan 2019 yang melalui JP, ciri- ciri centroid klaster: angkatan 2019 menjadi 2 klaster. Dan dua klaster tersebut mempunyai rata-rata IPS1 berbeda jauh yaitu klaster 1 dengan rata-rata IPS 1 sebesar 2,64 sedang klaster 2 sebesar 3,13.Perbedaan yang menyolok dari dua klaster itu adalah klaster dengan rata-rata IPS1 yang tinggi status SMAnya adalah Swasta dan lokasi SMA di Jawa. 
Sedangkan klaster dengan IPS1 yang rendah adalah status SMAnya adalah Negeri dan lokasi SMA di luar Jawa. Sedangkan berdasarkan Tabel 6-7 berikut ini adalah ciri-ciri klaster yang muncul pada dataset mahasiswa Non Jalur Prestasi (NJP) . Berikut adalah analisis klasternya.

- Untuk angkatan 2008 yang melalui NJP, ciri- ciri centroid klaster: angkatan 2008 menjadi 7 klaster. Klaster 2 mempunyai karakteristik mahasiswa dengan rata-rata IPS 1 yang tertinggi dan mempunyali level bahasa Inggris = 3 dan 4. Sedangkan klaster 4 mempunyai karakteristik IPS 1 terendah dia antara 7 klaster selain itu klaster 4 mempunyai level bahasa Inggris di level 1. Yang menonjol dari klaster 2 adalah, ia juga mempunyai nilai verbal yang tinggi yaitu 153,86.

- Untuk angkatan 2009 yang melalui NJP, berikut ciri- ciri centroid klaster: angkatan 2009 menjadi 2 klaster. Dan dua klaster tersebut mempunyai rata-rata IPS1 berbeda jauh yaitu klaster 1 dengan rata-rata IPS1 sebesar 2,81 sedang klaster 2 sebesar 2,04.Perbedaan yang menyolok dari dua klaster itu adalah klaster dengan rata-rata IPS1 yang tinggi status SMAnya adalah Swasta dan lokasi SMA di Jawa. Sedangkan klaster dengan IPS1 yang rendah adalah status SMAnya adalah Negeri dan lokasi SMA di luar Jawa. Klaster dengan IPS1 yang tinggi juga mempunyai kecenderungan nilai Numerik, Verbal, Spatial dan Analogi lebih tinggi daripada klaster dengan IPS1 yang rendah .

- Untuk angkatan 2010 yang melalui NJP, ciri- ciri centroid klasternya: angkatan 2010 menjadi 3 klaster. Klaster 3 mempunyai rata-rata IPS 1 tertinggi, klaster 2 mempunyai rata-rata IPS1 terendah sedangkan klaster 1 mempunyai rata-rata IPS1 yang sedang. Karakteristik klaster 3 adalah mempunyai rata-rata nilai Numerik, Verbal, Spatial dan Analogi yang tertinggi dibanding dua klaster lainnya. Dan klaster 2 mempunyai rata-rata nilai Numerik, Verbal, Spatial dan Analogi yang terendah dibanding dua klaster lainnya..Sedangkan klaster 1 mempunyai rata-rata nilai Numerik, Verbal, Spatial dan Analogi yang sedang.

- Untuk angkatan 2011 yang melalui NJP, berikut ciri- ciri centroid klaster: angkatan 2011 menjadi 2 klaster. Dan dua klaster tersebut mempunyai rata-rata IPS1 berbeda jauh yaitu klaster 1 dengan rata-rata IPS1 sebesar 1,72 sedang klaster 2 sebesar 2,12. Perbedaan yang menyolok dari dua klaster itu adalah klaster dengan rata-rata IPS 1 yang tinggi status SMAnya adalah Swasta dan lokasi SMA di Jawa. Sedangkan klaster dengan IPS1 yang rendah adalah status SMAnya adalah Negeri dan lokasi SMA di luar Jawa. Klaster dengan IPS1 yang tinggi juga mempunyai kecenderungan nilai Numerik, Verbal, Spatial dan Analogi lebih tinggi daripada klaster dengan IPS1 yang rendah.

- Untuk angkatan 2012 yang melalui NJP, ciri- ciri centroid klaster: angkatan 2012 menjadi 2 klaster. Dan dua klaster tersebut mempunyai rata-rata IPS1 berbeda jauh yaitu klaster 1 dengan rata-rata IPS1 sebesar 2,81 sedang klaster 2 sebesar 1,86. Perbedaan yang menyolok dari dua klaster itu adalah klaster dengan rata-rata IPS1 yang tinggi status SMAnya adalah Swasta dan lokasi SMA di Jawa.
Sedangkan klaster dengan IPS1 yang rendah adalah status SMAnya adalah Negeri dan lokasi SMA di luar Jawa. Klaster dengan IPS1 yang tinggi juga mempunyai kecenderungan nilai Numerik, Verbal, Spatial dan Analogi lebih tinggi daripada klaster dengan IPS1 yang rendah .

- Untuk angkatan 2013 yang melalui NJP, ciri- ciri centroid klaster: angkatan 2013 menjadi 3 klaster. Klaster 3 mempunyai rata-rata IPS 1 tertinggi, klaster 1 mempunyai rata-rata IPS1 terendah sedangkan klaster 2 mempunyai rata-rata IPS1 yang sedang. Karakteristik klaster dengan rata-rata IPS1 tertinggi adalah mempunyai rata-rata nilai Numerik, Verbal, Spatial dan Analogi yang tertinggi dibanding dua klaster lainnya.

- Untuk angkatan 2014 yang melalui NJP, ciri- ciri centroid klaster: angkatan 2014 menjadi 2 klaster. Klaster 1 dengan rata-rata IPS1 sebesar 2,19 sedang klaster 2 sebesar 2,06. Klaster dengan IPS1 yang tinggi juga mempunyai kecenderungan nilai Numerik, Verbal, Spatial dan Analogi lebih tinggi daripada klaster dengan IPS1 yang rendah.

- Untuk angkatan 2015 yang melalui NJP, ciri- ciri centroid klaster: angkatan 2015 menjadi 3 klaster. Klaster 1 mempunyai rata-rata IPS 1 tertinggi, klaster 3 mempunyai rata-rata IPS 1 terendah sedangkan klaster 2 mempunyai rata-rata IPS1 yang sedang . Karakteristik klaster dengan rata-rata IPS1 tertinggi adalah mempunyai rata-rata nilai Numerik, Verbal, Spatial dan Analogi yang tertinggi dibanding dua klaster lainnya.

- Untuk angkatan 2016 yang melalui NJP, ciri- ciri centroid klaster: angkatan 2016 menjadi 2 klaster. Klaster 1 dengan rata-rata IPS1 sebesar 2,12 sedang klaster 2 sebesar 2,51. Klaster dengan IPS1 yang tinggi juga mempunyai kecenderungan nilai Numerik, Verbal, Spatial dan Analogi lebih tinggi daripada klaster dengan IPS1 yang rendah.

- Untuk angkatan 2017 yang melalui NJP, berikut ciri- ciri centroid klaster: angkatan 2017 menjadi 3 klaster. Klaster 1 mempunyai rata-rata IPS 1 tertinggi, klaster 3 mempunyai rata-rata IPS1 terendah sedangkan klaster 2 mempunyai rata-rata IPS1 yang sedang. Karakteristik klaster dengan rata-rata IPS1 tertinggi alah mempunyai rata-rata nilai Numerik, Verbal, Spatial dan Analogi yang tertinggi dibanding dua klaster lainnya.

- Untuk angkatan 2018 yang melalui NJP, ciri- ciri centroid klaster: angkatan 2018 menjadi 2 klaster. Klaster 1 dengan rata-rata IPS1 sebesar 2,67 sedang klaster 2 sebesar 2,46. Klaster dengan IPS1 yang tinggi juga mempunyai kecenderungan nilai Numerik, Verbal, Spatial dan Analogi lebih tinggi daripada klaster dengan rata-rata IPS1 yang rendah.

- Untuk angkatan 2019 yang melalui NJP, ciri- ciri centroid klaster: angkatan 2019 menjadi 2 klaster. Klaster 1 dengan rata-rata IPS1 sebesar 2,82 sedang klaster 2 sebesar 2,56. Klaster dengan IPS1 yang tinggi juga mempunyai kecenderungan nilai Numerik, Verbal, Spatial dan 
Analogi lebih tinggi daripada klaster dengan rata-rata IPS1 yang rendah .

Berdasarkan hasil dari Tabel 8 , ternyata terlihat bahwa ratarata nilai kemampuan Numerik, Verbal, Spatial dan Analogi cenderung menurun dari angkatan 2008 sampai dengan 2019. Mulai tahun 2017 terlihat bahwa rata-rata IPS1 mulai mengalami peningkatan.

\section{KESIMPULAN}

Dari hasil penelitian terhadap dataset yang telah dilakukan akhirnya diperoleh beberapa beberapa kesimpulan sebagai berikut :

1. Dengan menggunakan data mahasiswa angkatan 2008 sampai dengan 2019, ternyata penggunaan TwoStep Klastering tidak mengelompokkan data menjadi banyak klaster yang sama. Banyaknya klaster pada dataset ini bervariasi dari 2 sampai dengan 7 klaster.

2. Angkatan yang sangat bervariasi (heterogen) yaitu angkatan yang terkelompok menjadi sejumlah klaster yang banyak. Dalam hal ini mahasiswa Jalur Prestasi angkatan 2012 menjadi 6 klaster dan mahasiswa Non Jalur Prestasi Angkatan 2008 menjadi 7 klaster.

3. Untuk mahasiswa Non Jalur Prestasi yang terkelompok menjadi dua klaster ternyata klaster dengan IPS1 yang tinggi juga mempunyai kecenderungan nilai Numerik, Verbal, Spatial dan Analogi lebih tinggi daripada klaster dengan rata-rata IPS1 yang rendah.

Saran yang dapat diterapkan pada penelitian ini adalah kemungkinan penelitian yang akan datang bisa mempertimbangkan program studi mahasiswa, karena Fakultas Teknologi Informasi mempunyai dua prodi yaitu Prodi Informatika dan Prodi Sistem Informasi.

\section{UCAPAN TERIMA KASIH}

Penelitian ini dapat terlaksana dengan baik berkat dukungan dana penelitian dari Lembaga Penelitian dan Pengabdian Masyarakat Universitas Kristen Duta Wacana, skema Penelitian Unggul Universitas dengan nomor kontrak 061/D.01/LPPM/2020.

\section{REFERENSI}

[1] J. Campbell and O. Oblinger, Academic Analytics, Washington: DC: Educause, 2007.

[2] R. Baker and K. Yacef, "The State of Educational Data Mining in 2009: A review and Future Visions," Journal of Educational Data Mining , I(1), 2009

[3] D. Alverina, A. R. Chrismanto and R. G. Santosa, "Perbandingan Akurasi Algoritma C4.5 dan CART dalam Memprediksi Kategori Indeks Prestasi Mahasiswa," Jurnal Teknologi dan Sistem Komputer Volume 6 , No. 2 April 2018, pp. 76-83, 2018.

[4] R. G. Santosa, A. R. Chrismanto and E. Kurniawan, "Analisis Cluster Terhadap Karakteristik Mahasiswa Jalur Prestasi UKDW," Jurnal Edukasi \& Penelitian Informatika (JEPIN) Vol.6, No.1, April 2020, pp. 13-22, 2020

[5] D. Schiopu, “Applying TwoStep Cluster Analysis for Identifying Bank Customers' Profile," BULETINUL, pp. 66-75, 2010.

[6] C. E. Mongi, "Penggunaan Analisis TwoStep Clustering untuk Data Campuran," d'Cartesian : Jurnal Matematika dan Aplikasi Vol. 4 No. 1 Maret 2015, pp. 9-19, 2015.
[7] J. Cho and S. Kim, "Highway Characteristic Classification Using TwoStep Clustering Algorithm : Methodology and Case Study in Korea," in Proceedings of The Eastern Asia Society for Transportation, 2009.

[8] M. Trpkova and D. Tevdovski, "Challenges for Analysis of The Economy, The Bussinesses and Social Progress," Makedonia, 2007.

[9] N. D. Moroke, "A TwoStep Clustering ALgorithm as Applied to Crime Data of South Africa," Corporate Ownership \& Control Volume 12, issue 2, winter 2015, pp. 482-490, 2015.

[10] S. M. Satish and S. Bharadhwaj, "Information Search Behaviour Among New Car Buyer," IIMB Management Review(2010) 22, pp. 5-15, 2010.

[11] O. Dwipurwani, "Penerapan Metode TwoStep Cluster Analysis (TCA) pada Pengelompokan Mahasiswa Matematika MIPA UNSRI Berdasar Cara Belajar," in Prosiding Semirata FMIPA Universitas Lampung , Lampung, 2013.

[12] N. Setiyawati and D. H. Bangkalang, "Penerapan Metode Two-Step Cluster dalam Analisis Menu Engineering pada Usaha Kuliner," Jurnal Teknologi Informasi dan Ilmu Komputer (JTIIK) Vol. 7, No. 2, April 2020, pp. 359-366, 2020.

[13] I. A. Hapsari, D. Kusnandar and N. Imro'ah, "Metode TwoStep Cluster Dalam Mengelompokkan Mahasiswa FMIPA UNTAN," Buletin Ilmiah Math. Stat. dan Terapannya (Bimaster), pp. 173-180, 2020.

[14] J. Bacher, K. Wenzig and M. Vogler, "SPSS TwoStep Cluster - a First Evaluation," Universitat Erlangen-Nurnberg, 2004.

[15] W. K. Hardle and L. Simar, Applied Multivariate Statistical Analysis 4th edition, Berlin: Springer-Verlag Berlin Heidelberg, 2015.

[16] B. Swarbrick, Multivariate Data Analysis for Dummies CAMO Software Special edition, John Wiley \& Sons, LTD Chichester, 2012.

[17] A. K. Wardhani, "K-Means Algorithm Implementation for Clustering of Patients Disease in Kajen Clinic of Pekalongan," Jurnal TRANSFORMATIKA Volume 14 Nomor 1, July 2016, pp. 30-37, 2016.

[18] M. Singh, A. Rani and R. Sharma, "An Optimised Approach For Student's Academic Performance By K-Means Clustering Algorithm Using Weka Interface," International Journal of Advanced Computational Engineering and Netrworking ISSN 2320-2106, Volume2, Issue-7 July 2014, pp. 2-9, 2014.

[19] J. Han, M. Kamber and J. Pei, Data Mining : Concepts and Techniques, Morgan Kaufmann Publishers, 2011. 